
\title{
25 Research Square \\ Integrated geophysical approach for Coal mine fire in Jharia coalfield, India
}

\section{Sanjit Kumar Pal ( $\nabla$ sanjitismagp@iitism.ac.in )}

Indian Institute of Technology(Indian School of Mines) Dhanbad https://orcid.org/0000-0002-47202959

\section{Sahadev Kumar}

Indian Institute of Technology(Indian School of Mines) Dhanbad-826004

\section{Shalivahan Srivastava}

Indian Institute of Technology (Indian School of Mines) Dhanbad 826004

\section{Research Article}

Keywords: Surface temperature measurement, Magnetic method, Electrical resistivity tomography method, coal fire mapping, Jharia coalfield, India

Posted Date: March 22nd, 2021

DOl: https://doi.org/10.21203/rs.3.rs-302068/v1

License: (1) (1) This work is licensed under a Creative Commons Attribution 4.0 International License. Read Full License 


\section{Abstract}

Jharia coalfield is one of India's largest and most productive coal fields, home of the oldest-burning coal seam fires in the world. This paper highlights the combined study comprising Surface Temperature measurement, Magnetic, and Electrical Resistivity Tomography (ERT) methods for delineation and mapping of coal fires with their depths, extension and propagation direction. Surface temperature mapping allows straight forward demarcation of coal fire areas. Magnetic data provide a map showing the earlier burned, currently burning and unburned patches based on the contrast between magnetic effects of the subsurface and fluctuations with temperatures exceeding or under the Curie temperature. The pyrolysis of coal is one of the main processes in coal fires, which results in very high conductivity. Thus, electrical resistivity tomography (ERT) is also a promising technique for the characterization of a coal fire-affected area. Most of the features of low and high resistivity associated with active fires and voids have been delimited well in the ERT sections that are generated from combine inversion of all arrays. These are also delineated well by the surface temperature mapping, and Magnetic methods. The field photographs, available coal seam and borehole lithology clearly show the suitability of the combined study for characterization of coal seam fire. A model of the coal fire, char formation and void formation resulting from coal seam fire has been established. Finally, a fire propagation model of the study area has been established based on the combined geophysical data that can be effectively used for mine hazard mitigation.

\section{Introduction}

Thousands of coal mines fires are reported to be burning in at least 22 countries throughout the globe (Stracher, 2010). Coal fires are common worldwide problems posing severe hazards to valuable energy sources, environments and human lives. China, United States, India, South Africa (Prakash and Gupta 1998; Stracher 2004; Mishra et al. 2011; Pal et al. 2016; Srivardhan et al. 2016), Indonesia, Russia, Poland and Australia (Ide et al. 2011; Ide and Orr 2011) are severely victimized by coal fires. The coal fires may be caused by illegal mining activities, exothermic reactions, lighting, forest fire and anthropogenic activities which can smoulder underground coal for several years and may continue for hundreds of years. The ignition of underground coal fires activities is a chaotic process comprising numerous illdefined variable parameters, such as:

- greenhouse gases, e.g., methane (CH4), carbon dioxide $\left(\mathrm{CO}_{2}\right)$, (Schloemer 2006; Litschke et al. 2008; Schloemer et al. 2008),

- toxic gases, e.g., nitrogen $\left(\mathrm{N}_{2}\right)$, ammonia $\left(\mathrm{NH}_{3}\right)$, sulphur dioxide $\left(\mathrm{SO}_{2}\right)$, hydrogen, carbon monoxide (CO) (Kuenzer et al. 2007b),

- trace elements, e.g., mercury (Hg), selenium (Se), Arsenic (As), (Dai et al., 2012; Zhang, 2008), and

- various unsaturated hydrocarbons, sulphur, $\mathrm{H} 2 \mathrm{O}$ vapour, asphalt vapour, organic, inorganic chlorides and hydrogen chlorides, etc. (Engle et al. 2011; Xie et al. 2011; Song and Kuenzer 2014; Gürdal et al. 
2015; Pal et al. 2016) which threaten the local environment and healthiness of public alive in the surrounding areas.

The delineation of a concealed underground coal fire is of utmost importance to establish scientific and administrative strategies to control and extinguish or rehabilitation of local establishment.

In the 1960s, the borehole drilling (Kuenzer 2015) and surface temperature measurements (Mukherjee et al. 1991; Saraf et al. 1995; Gangopadhyay et al. 2006) were widely used for coal fire studies, which were costly affairs and time-consuming (Shao et al. 2014). Afterwards, thermal infrared (Bhattacharya et al. 1991; Mukherjee et al. 1991; Cracknell and Mansor; 1992; Mansor et al. 1994; Bhattacharya and Reddy, 1994; Saraf et al. 1995; Prakash et al. 1997; Prakash and Gupta, 1999; Chatterjee, 2006; Kuenzer et al. 2007a,b, 2008; Mishra et al. 2011; Gangopadhyay, 2006, 2012; Gautam et al. 2008, 2012; Guha and Kumar, 2012; Song and Kuenzer 2014; Roy et al. 2015; Pandey et al. 2017; Syed et al. 2018; Ghosh et al. 2020) and Synthetic Aperture Radar (Bhattacharya et al. 2012; Gupta et al. 2006, 2013, 2014; Chatterjee et al. 2015; Syed et al. 2018) remote sensing techniques have been most widely utilized for study of the deadly coal fires in Jharia/ Raniganj coalfields (). These studies have revealed that only the shallow coal fires could be mapped but it is quite difficult to map deeper coal fires (Shao et al. 2016; Syed et al. 2018). However, King (1987) conducted a transient-electromagnetic study over Cindered coal seams in Australia and identified coal fires to a depth of $340 \mathrm{~m}$. Further, over the last decades, several techniques have been developed to delineate and monitor the coal fires such as,

- index gas measurements (Xie et al. 2011),

- radon gas measurements (Xie et al. 2011),

- ground temperature measurement (Litschke et al., 2008; Kuenzer et al., 2012),

- self-potential (SP) method (Rodriguez 1983; Revil and Jardani 2013; Revil et al., 2013; Karaoulis et al. 201; Shao et al. 2014; Singh 2015, 2019; Srivardhan et al., 2016, Mishra et al. 2018; Kumar and Pal 2020),

- magnetic method (Sternberg and Lippincott 2004; Ide et al. 2011; Kumar et al. 2015; Shao et al. 2014; Vaish and Pal 2015, 2016; Pal et al. 2016,2017; Mishra et al. 2018),

- ground penetrating radar method (Gudelach, 2010),

- controlled source audio magnetotelluric (CSAMT) method (Bartel, 1982),

- the time-domain electromagnetic technique (King 1987; Schaumann et al. 2008) and

- electrical resistivity profiling/imaging (Corwin and Hoover 1979; Gangopadhyay 2003; Rodriguez 1983; Revil et al. 2013; Karaoulis et al. 2014; Xin et al. 2015; Pal et al., 2016; Bhattacharya and Shalivahan 2016; Bharti et al. 2016a, Shao et al. 2016; Mishra et al. 2018).

The coal fires have been studied by many researchers, mainly using satellite remote sensing data over Jharia coalfield and its surroundings. Bhattacharya et al. (1991)) exploited aerial thermal data for the mapping of coal fires and its depth of occurrence, in the Jharia coalfield, using linear heat flow equation. Saraf et al. (1995) and Prakash and Gupta (1998) established the effectiveness of space-borne thermal 
data (Landsat-5 TM) for the identification of coal fires in the area. Prakash et al. (1997) carried out a comparative study of surface and subsurface fires using Landsat TM. Agarwal et al. (2006) conducted coal mine fires in the Jharia coalfield using NOAA/AVHRR data. Chatterjee (2006) established a technique of pixel integrated temperature modelling on Landsat TM thermal IR images for understanding the dynamics of the coal fire. Mishra et al. (2011), empirically, appraised a scaled deviation between the temperature of the surface and underground coal fires. They established it from the thermal band of Landsat ETM+ data and in-situ temperature observations using thermal imaging camera. Further, in recent years geophysical studies, mainly, magnetic (Vaish and Pal 2013, 2015, 2016; Singh and Pal 2015; Kumar et al. 2015; Pal et al. 2016, 2017) , SP (Bharti et al. 2014; Singh et. 2015, 2019; Srivardhan et al. 2016, Mishra et al. 2018; Kumar and Pal 2020; Srivardhan et al., 2016) and electrical resistivity (Gangopadhyay 2003; Pal et al. 2016; Mishra et al. 2018) have been carried out to map coal fire in the Jharia coalfield and surroundings. In this paper, the first time in India we have attempted an integrated geophysical approach comprising surface temperature measurement, magnetic, and electrical resistivity tomography (ERT) studies for detection of concealed subsurface coal fire zones over Akashkinaree Colliery to impart a review for suitability of coal fire study in Jharia coalfield using geophysical methods.

\section{Details Of The Study Area}

In India, Jhaia coalfield is famous for coal mine fires. Here coal fire was first reported in 1916. About 40 million tons of coal have been consumed, and about 1.5 billion tons of coal are inaccessible due to fire (Stracher 2010). Jharia will continue to burn until effective prevention, and extinguishment procedures are developed and employed, or the coal burns out. Considering the amount of coal that has burnt since 1916 , it is estimated that if all the remaining inaccessible coals are left to burn at the same average rate, the fires will continue for another 3,800 years (Stracher 2010). Approximately 77 coal mine fires have been reported (Michalski 2004; Mishra et al. 2011). Government of India is determined for rehabilitation and resettlement of the people from 595 endangered sites and diversion of railway tracks and roads, making it easier to douse the underground fires that have burned for a century and huge mine reserves of premium coal (http://timesofindia.indiatimes.com/city/kolkata, 10 Feb 2016). Keeping the safety of people, Ministry of Railways, Government of India has decided to stop/divert the operation of goods and passenger traffic on Dhanbad-Chandrapura Railway line (Figure 1) approximately $400 \mathrm{~m}$ from the study area since 15 June 2017 due to the Jharia coalfield Fire (http://www.newindianexpress.com/nation/2017/jun/12/coal-mine-fire-railways-to-close-section-injharkhand-1615847.html). This is expected to cause huge revenue loss to Indian railways. The fiery deposits of Jharia coalfield in India, are mainly valued because they are the only source of high-quality coking grade coal in the country. India spends Rs.300 billion rupees a year on importing that grade alone (http://in.reuters.com / article/india-coal-mines-modi-idINKBN0OG01R20150531). Government of India hopes to increase production at the blazing mine. The effects of the coal fire and associated carbon emissions played a serious concern on climate change at the COP21 summit in Paris (http://www.cnbc.com/2015/12/02). 
Jharia coalfield covers areal spreads approximately $456 \mathrm{sq}$. Km (fox1930) and the basin extends $38 \mathrm{~km}$ in East-West direction and $18 \mathrm{~km}$ in North-South direction. The coalfield has 46 seams in Barakar formation, and 26 coal seams in Raniganj formation, and rests are local seams (Sengupta 1980). As per the quality, coal of Barakar formation is superior to Raniganj formation. It has a thick sedimentary sequence approximately $2900 \mathrm{~m}$ associated with Carboniferous to Permian age. The coalfield is bounded by metamorphic rocks and the basin is mainly consists sandstone of Talchir, Barakar, barren measures and Raniganj formation. (CMPDI 1988). Figure 1 shows the generalized geological map of Jharia coalfield and location of Akashkinaree Colliery, Jharia Coalfield. Borehole litholog indicating coal seams with depth is shown in Fig.2.

\section{Methodology}

The present study deals with an integrated study comprising surface temperature measurement, magnetic and electrical resistivity tomography (ERT) methods for mapping of coal fires with their depths, extension and propagation direction. The heat transmission from the underground combustion zone to the surface is a prolonged process, which involves convection and gas emissions through cracks/fissures/vents. These are the main sources of surface thermal anomalies. This technique is costefficient and may provide high accuracy for delineation of surficial location and extent. Although it is time-consuming; it could not be used for depth estimation of the combustion zone. It is also affected by air circulation and ambient conditions, for example, solar radiation, wind, and precipitation (Song and Kuenzer 2014).

The underground coal combustion and rise in temperature of overlying formation result in significant changes in magnetic susceptibility and thermo-remanent magnetization (Shao et al. 2014). Magnetism rises gradually with the increase of temperature till the Curie temperature. The overlying formation drops its magnetization and becomes paramagnetic due to heating above the Curie temperature. Afterwards, magnetism intensifies significantly due to cooling of the overlying formation below the Curie temperature (Shao et al. 2014; Pal et al. 2016).

Powell and Schofield (1939) examined the electrical resistivity of carbon and graphite at high temperatures. They observed that electrical resistivity decreases with thermal conductivity, similar to graphitization. Further, Northrop (1975) observed that in normal state the coal's resistivity varies from $\sim 100$ to $\sim 3000 \Omega \mathrm{m}$. In the pyrolysis process for temperatures greater than $\sim 650^{\circ} \mathrm{C}$, the resistivity of coal decreases approximately to $1 \Omega \mathrm{m}$ (Northrop 1975; Duba, 1977, 1983). This huge decrease in resistivity is due to the higher carbon content of char. Based on these studies, Duba (1977) recommended electrical resistivity technique for characterization of underground concealed coal seam fires.

The electrical resistivity tomography (ERT) has been used for detection and mapping of coal seam fire, its depth, extension, combustion centre, and the resulted cave or rubble zone. In the present study, ERT data have been collected using 61-channels 64 electrodes FlashRES-Universal ERT data acquisition system 
(ZZ Resistivity Imaging Pty Ltd, Australia). The acquisition involves imposing direct current into the ground using two current electrodes, and the potentials are measured at remaining 62 electrodes. This results in 61 potential differences with respect to a reference electrode (Fig.3). The choice of the reference electrode is dynamic and is always considered to be three spacing away from the position of the current electrodes through which the current is being injected (Zhe et al. 2007). The ERT data of multiple arrays have been collected in-one-go which support effective and faster data acquisition than the conventional systems (Zhe et al. 2007). The program considers both the quality and current threshold in noise analysis. Quality is defined as the standard deviation of the ratio of voltage to current and is expressed in percentage. The histogram of quality of the collected data versus frequency and average current values for all electrode pairs versus each electrode position is used to optimize the maximum number of data points for analysis considering current threshold and quality factor.

Bharti et al. (2016a) have analyzed ERT data collected for cavity detection over a coal fire-affected area using 3 different combinations of quality factor and current threshold, i.e., (i) $5 \%$ and $60 \mathrm{~mA}$, (ii) $12 \%$ and $40 \mathrm{~mA}$, and (iii) $17 \%$ and $10 \mathrm{~mA}$. They argued that the best result is obtained with minimum RMS error, with quality factor $5 \%$ and current threshold of $60 \mathrm{~mA}$. Further, Bharti et al. (2016b) analyzed ERT data collected for cavity detection using a fixed quality factor $5 \%$ with variable current thresholds $(50 \mathrm{~mA}$, $100 \mathrm{~mA}$ and $150 \mathrm{~mA}$ ). This study reveals that the best result is obtained with a minimum RMS error when the current threshold is $150 \mathrm{~mA}$ followed by $100 \mathrm{~mA}$. Generally, relatively noisy and inconsistent data are sieved out at higher current thresholds and decreasing order of quality factor.

In the present study, the collected data have been processed with quality factor $5 \%$ and the current threshold of $100 \mathrm{~mA}$ in FlashRES Universal survey data checking program (FlashRES Universal, User manual). These thresholds correspond to $94 \%$ (profile AA'), 95\% (profile BB') and 93\% (profile CC') of the acquired data covering a good amount of consistent data points (Figure 1). We have acquired data using Schlumberger, Wenner, Dipole-Dipole and Gradient arrays. Further, combined inversion of all filtered data collected by all arrays have been performed in a 2.5D resistivity tomography program developed by Zhou and Greenhalgh, (1999, 2000, 2001). Zhou and Greenhalgh (2000) and Dahlin and Zhou (2006) argued that the inversion of combined data (all arrays) would further optimize the resolution capability and signal-to-noise ratio. De la Vega et al. (2003), Stummer et al. (2004) and Athanasiou et al. (2007) argued that combined inversion provide the relative benefits associated with all the arrays and generate more realistic $2 \mathrm{D}$ subsurface resistivity section. The colour legend for all $2 \mathrm{D}$ electrical resistivity tomography sections are shown individually to highlights various anomalous resistivity variations associated with subsurface features (Bharti et al. 2016a, b; Shao et al. 2016; Gautam, and Biswas 2016; Srivastava et al. 2020).

\section{Results And Discussions}

Initially, surface temperature and magnetic data are collected at about 820 locations along 13 profiles at $5 \mathrm{~m}$ measurement spacing. The profile length varies from 200 to $500 \mathrm{~m}$. Each profile is almost parallel and separated approximately at $25 \mathrm{~m}$ line spacing, which covers an area of about $300 \mathrm{~m}$ width and $500 \mathrm{~m}$ 
length. The profiles are selected on the basis of existing plan and space over the study area for demarcation and mapping of underground coal seam fires. A base station is selected over a non-coal fire area. Repeated base station readings are collected at 30-minute interval to correct drift or diurnal variation. To achieve stable readings of surface temperature at each station were dug a small hole to eliminate the effect of top surface soil.

In-situ surface temperature measurement is carried out using Fluke 51 series-II Digital thermometer. The variation in the temperature data is about $5^{\circ} \mathrm{C}$. Drift corrected surface temperature anomaly map (Fig.4) shows variations from $\sim 90$ to $22^{\circ} \mathrm{C}$. Three prominent $(\mathrm{TH} 1, \mathrm{TH} 2$ and $\mathrm{TH} 3$ ) zones of high thermal anomalies are identified with black dotted lines which are possibly associated with fire in coal seam XVIC, $\mathrm{XVIB}$ and L1/L2, respectively. In addition, some more temperature anomaly zones (TH4, TH5) are identified in Fig.4. TH5 (denoted by white dashed lines) could be associated with burned and cooling of XVIA. The thermal anomalies are not following exactly as the anomaly might be related with a thermal vent and could not relate therefore to the exact horizontal position of the burning front itself (Prakash et al. 1995; Karaoulis et al. 2014).

The total magnetic field intensity (TMI) data are corrected for diurnal variations which is about 30nT over the study area. This collected data are adjusted according to the International Geomagnetic Reference Field (IGRF) in Geosoft Oasis Montaj. Further, reduced to North Magnetic Pole (RTP) anomaly map has been generated in Geosoft for removal of lateral shifts and asymmetries caused by the local orientation of the magnetic anomaly (Ide et al. 2011; Pal et al. 2016, 2017). The RTP anomaly map and its residual anomaly map are shown in Fig.5a and 5b. It is observed that RTP anomaly varies from $\sim 866$ to $-637 \mathrm{nT}$, whereas residual of RTP anomaly varies from $\sim 162$ to $-283 n$ T. From residual of RTP anomaly map, three prominent (RTPL1, RTPL2 and RTPL3) zones of negative magnetic anomalies have been demarcated that are possibly associated with underground fire in coal seam XVIC, XVIB and L1/L2. RTPH1 could be associated with burned and cooling of XVIA.

Different sets of Euler's depth solutions have been calculated for structural index $(\mathrm{SI})=0$ (represents contact, fault), 1 (represents thin sheet edge/ sill), 2 (represents vertical pipe and horizontal cylinder), and 3 (represents sphere) for the magnetic data (Reid et al. 1990) using Euler deconvolution technique. It finds probable tightest cluster of the solution associated with different complex coal fire source geometry and edges of coal fire front using various window sizes $(5 \times 5,10 \times 10,15 \times 15)$ and depth tolerances $(5 \%$, $10 \%$, and $15 \%$ ). Only a limited number of solutions are found in $\mathrm{SI}=0$, but a larger number of clustered solutions are observed in the higher order of $\mathrm{SI}(\mathrm{SI}=1,2$ and 3) except some additional clustered solutions of deeper depth. Reid et al. (1990) discussed that the depth estimation is more precise for higher SI. Thompson (1982) argued that most of the subsurface structures are better represented by higher indices, but lower indices are generally directly related to the depth to the top of structures. Relatively better clustering observed for a window size of $10 \times 10$ and depth tolerance $10 \%$ with SI=3 for magnetic data. The Euler's depth solutions of RTP anomaly $(\mathrm{SI}=3.0)$ is overlain on residuals of RTP anomaly (Fig.6a). Three clustering patterns EM1, EM2 and EM3 have been identified from Euler's depth solutions, which could be associated with fire in coal seam XVIC, XVIB and L1/L2 respectively (Fig.6a). 
Whereas EM4 could be associated with burned and cooling of XVIA (Fig.6a). Histogram of Euler's depth solutions of the RTP anomaly is shown in Fig. $6 \mathrm{~b}$. It is observed that about $20 \%, 40 \%, 15 \%, 9 \%, 11 \&, 3 \%$ and $2 \%$ of Euler's depth solutions using magnetic data occurred in the depth range of i) $10-15 \mathrm{~m}$ (seam L1 and L2 Fig.2), ii) 15-25m (seam XVIA, Fig. 2) and iii) 25 -30m (L3, Fig.2), iv) $30-37 m$ (seam XVIB Fig.2), v) 37-46m (seam XVIC and L4, Fig.2), vi) $47-50 \mathrm{~m}$ (seam L5, L6, Fig. 2), and vii) 50 -53m (seam L7, Fig. 2). It is observed that maximum solutions are occurring in $15-25 \mathrm{~m}$ associated with seam XVIA, followed by the Euler's depth solutions of 10-15m associated with seam L1 and L2. It indicates that fire intensity in seam XVIA is comparatively highest because of thick coal than the thin coal in L1/L1. Euler's depth solutions corresponding to depth ranges $25-30 m$ (seam L3), 30 -37m (seam XVIB), 37-46m (seam XVIC and L4), $47-50 \mathrm{~m}$ (seam L5, L6) and $50-53 \mathrm{~m}$ (seam L7) are decreasing because of insufficient oxygen supply to the deeper coal-seams.

Further, three parallel ERT lines $\left(\mathrm{AA}^{\prime}, \mathrm{BB}^{\prime}\right.$ and $\left.\mathrm{CC}^{\prime}\right)$, each of $5 \mathrm{~m}$ electrode spacing with $315 \mathrm{~m}$ profile length, are selected to validate the study of surface temperature and magnetic data. The origin point of each profile, i.e., 1st electrode position is considered as the reduced distance (RD) as $0 \mathrm{~m}(A, B, C)$ and end of the profiles, i.e., $64^{\text {th }}$ electrode position is considered as RD $315 \mathrm{~m}\left(\mathrm{~A}^{\prime}, \mathrm{B}^{\prime}, \mathrm{C}^{\prime}\right)$. Figures $7-9$ show the $2 \mathrm{D}$ resistivity tomography sections of lines $\mathrm{AA}^{\prime}, \mathrm{BB}^{\prime}$ and $\mathrm{CC}^{\prime}$, respectively. Each figure contains $2 \mathrm{D}$ tomography sections estimated by (a) Wenner, (b) Schlumberger, (c) Dipole-Dipole, (d) Gradient, and (e) combined arrays with the fixed quality factor $5 \%$ and current threshold of $100 \mathrm{~mA}$. The graphical plot (Fig.10) of root means square (RMS) errors for the inverted resistivity sections indicates that minimum RMS error is observed in the inversion of ERT data combining all arrays tailed by Gradient, Dipole-Dipole, Schlumberger and Wenner.

The different possible subsurface features, e.g.,, coal fire, void generated by coal-fire and shale/clay stone/sandstone are delineated in resistivity tomography sections (lines $\mathrm{AA}^{\prime}, \mathrm{BB}^{\prime}$ and $\mathrm{CC}^{\prime}$ ) based on resistivity variations in subsurface formation. It is observed from Figs. 7-9 (Tables 1-3) that most of the resistivity (both resistive and conducting) signatures are well resolved in combined inversion of all arrays (Figs.7e, 8e, and 9e). Generally, any individual array barely delineates all the signatures. In general, the resistivity signatures identified by the joint inversion of all arrays is mainly the combination of the signatures/features of each array. These consequences are in accordance with the earlier observations that shows the effectiveness of the combined inversion of collective data sets (Vega et al., 2003; Athanasiou et al., 2007; Bharti et al., 2016a, 2016b). It is observed that the joint data (Wenner, Schlumberger, Gradient and Dipole-Dipole) carry supplementary evidence compared to a single array data set (Stummer et al. 2004; Athanasiou et al. 2007) .

The field photographs of active fires through fissures, cracks are shown in Figs. 11a,b,c. The corresponding low resistivity anomalies of coal seam fire are delineated in the resistivity tomography sections of lines $\mathrm{AA}^{\prime}$ ( RESL3), BB' (RESL2) and CC' (RESL1). Figures $11 \mathrm{~d}$,e,f are the respective thermal images. Thermal images indicate that the temperature varies in the range of $214-258{ }^{\circ} \mathrm{C}$ over the active fire vents/fissures with the surrounding temperature of about $44^{\circ} \mathrm{C}$. Further, the field photographs 
indicating numerous secondary and higher-order fractures/crack/fissures, pothole of old coal fireaffected areas are shown in Figs.12 a, b, c, d. The corresponding high resistivity anomalies due to voids formation have been delineated in the resistivity tomography sections along the lines $A A^{\prime}(R E S H 3), B^{\prime}$ (RESH2 and RES4) and CC'(RESH1).

A schematic model of fire propagation over the Akashkinaree Colliery, Jharia coalfield (Fig.13) has been generated based on the resistivity tomography sections of the lines $\mathrm{AA}^{\prime}, \mathrm{BB}^{\prime}$ and $\mathrm{CC}^{\prime}$. Four highly conductive (RESL1, RESL2, RESL3 and RESL4) zones and one high resistive (RESH1) zone have been identified . Along profile AA', two prominent low resistivity anomalies of $\sim 20 \Omega \mathrm{m}$ (RESL1) and $\sim 10 \Omega \mathrm{m}$ (RESL3) associated with active coal fires have been delineated at depths of $\sim 25$ (RD 50m) and $\sim 35 \mathrm{~m}$ (RD 160m), which correspond with the coal seam XVIC and XVIB (Fig.2), respectively. RESL1 corresponds with TH1, RTPL1, and EM1, whereas RESL3 corresponds with TH2, RTPL2, and EM2. Further, a prominent high resistivity anomaly of $\sim 500 \Omega \mathrm{m}$ (RESH1) at a depth of $\sim 35 \mathrm{~m}$ and RD $240 \mathrm{~m}$, has been delineated as a void due to complete combustion of coal seam XVIA and different local seams (Figs.2 and L3). RESH1 could be correlated with TH5, RTPH1, and EM4. Along the profile BB', a prominent low resistive signature of $\sim 10 \Omega \mathrm{m}$ (RESL3) has been delineated at a depth of $\sim 40 \mathrm{~m}$ and RD $175 \mathrm{~m}$, due to active coal fire in coal seam XVIB and local seams (Figs.2 and L3). A high resistivity anomaly of $\sim 700 \Omega \mathrm{m}$ at RD $250 \mathrm{~m}$ associated with a void at a depth of $\sim 20 \mathrm{~m}$ have been delineated corresponding to the complete combustion of coal seam XVIA and local seams. In addition, a relatively high resistivity anomaly of $\sim 320$ $\Omega \mathrm{m}$ at RD $75 \mathrm{~m}$ associated with a void at a depth of $\sim 42 \mathrm{~m}$ have been delineated corresponding to the partial combustion of coal seam XVIC and local (L3) seams (Figs.2). Similarly, a low resistive zone with resistivity of $\sim 10 \Omega \mathrm{m}$ (Res-L3, $\sim 258^{\circ} \mathrm{C}$ of Fig.13f) due to active coal fire in coal seam XVIB at depths of $\sim$ $30 \mathrm{~m}$ at RD145m has been delineated along profile $C^{\prime}$. Two high resistive zones of $\sim 300$ and $\sim 400 \Omega \mathrm{m}$ resistivity at depths of $\sim 30$ and $\sim 35 \mathrm{~m}$ with RD50 and RD220m have been delineated as voids due to complete combustion of coal seams XVIC and XVIA, respectively. The low resistive zones RESL4 and RESL2 at a depth of $\sim 9$ to $15 \mathrm{~m}$ have been observed in all three profiles, which are possibly due to burning of the different thin local coal seam at shallow depth (Figs.2 and 13). RESL4 could be correlated with TH3, RTPL3, and EM3. The low resistive zone Res-L2 is not correlated well with the surface temperature, magnetic data. In addition, a number of small low resistivity patches near the surface are observed which may not be directly related to coal fires. These are possibly cracks and small potholes filled with moist soil/debris. These potholes are generated from secondary fractures during complete combustion phase. The moist soil/debris in near-surface cracks/fissures/potholes generates vapour/smoke due to underneath coal fire activities, which results in relatively low resistivity anomaly (Shao, 2016). The voids (RESH1) with resistivity range $\sim 300$ to $700 \Omega$ m have been demarcated in all the lines $\mathrm{AA}^{\prime}, \mathrm{BB}^{\prime}$ and $\mathrm{CC}^{\prime}$. Although, the air-filled cavities indicate extremely high resistivity values. Previous studies (Ezersky 2008 and Bharti et al. 2016a) established based on synthetic modeling that the airfield cavities are appeared to be relatively low resistive cavity in the inverted resistivity tomography section due to the assorted and multifarious subsurface assorted coal mine environment. 
Shao et al. (2016) examined electrical resistivity variations of different coal-bearing rocks with very low resistivity at $\sim 700^{\circ} \mathrm{C}$ temperature. Moreover, the very low resistivity at the burning centre of a coal fireaffected area performs a crucial role in decreasing resistivity of the overburden sedimentary rocks and rock-forming minerals. Some micro-fractures occurred on exceeding thermal stress beyond the critical strength of the rock. Subsequently, they join each other resulting with macro cracks, which collectively further lead to the formation of major cracks, fractures, potholes, and fissures enhancing the electrical resistivity.

A conceptual model (modified after Bharti et al. 2016a) for coal combustion, char and void formation resulting from coal seam fire is shown in Fig.14. The underground coal seam fire activities are chaotic process involving numerous ill-defined functions, which lead to the formation of char from the pyrolysis process at a temperature of $\sim 650{ }^{\circ} \mathrm{C}$. The resulted volatile $+\mathrm{O}_{2}$, and char $+\mathrm{O}_{2}$ create an exothermic environment which generates a huge amount of heat developing micro fractures. Further, enormous heats create numerous primary and secondary fractures/cracks/fissures, in the overlying rock strata which are exposed to the surface. Numerous primary and secondary fractures/cracks/fissures lead to high $\mathrm{O}_{2}$ circulation for complete combustion of char and associated volatiles with enhanced cavities caused by volume reduction due to the transformation of coal to char and further to ashes mixed with rock debris.

\section{Conclusions}

Delineation and mapping of coal mine fires have been carried out by combined study comprising surface temperature measurement, magnetic, and electrical resistivity tomography methods over a fire-affected area around the Akashkinaree Colliery, Jharia coalfield, India. Three prominent zones have been demarcated based on combined observations, surface temperature (TH1, TH2 and TH3), and RTP of magnetic data (RTPL1, RTPL2 and RTPL3), which are related with underground fires in coal seam XVIC, $\mathrm{XVIB}$ and L1/L2. A zone associated with burned and cooling of coal seam XVIA has also been delineated separately with the surface temperature (TH5) and RTP of magnetic data (RTPH1). The clustering patterns of Euler's depth solutions for magnetic (Fig.6a) signatures are also corroborated well with the different coal seams. The varying range of SI values with similar clustering pattern indicate complex nature of possible fire source geometry of spherical zones or fire propagation along different inclined/horizontally extended fractured planes/vertical cylindrical opening through potholes, which are generated in multiphase coal seam burning associated with various complex coal fire activities.

Resistivity tomography sections generated by the inversion of combined data (all arrays) clearly delineate active coal seam fires and associated voids compared to an individual array (Wenner, Schlumberger, Gradient, Dipole-Dipole). The schematic model (generated by inversion of combined arrays in lines AA', $\mathrm{BB}^{\prime}$ and $\mathrm{CC}^{\prime}$ ) of fire propagation delineates four highly conductive zones (RESL1, RESL2, RESL3 and RESL4) and one highly resistive zone (RESH1). RESL1 is associated with fire in coal seam XVIC, which corresponds with TH1, RTPL1 and EM1. Res-L3 is associated with fire in coal seam XVIB corresponds with TH2, RTPL2, and EM2. Res-L4 associated with fires in local coal seam-L2 corresponds with TH3, 
RTPL3, and EM3. Res-H1 is resulted due to burning of coal seam XVIA leading to void formation that corresponds with TH5, RTPH1, and EM4. The depth range of the estimated Euler's solutions is well correlated with the depth estimated using ERT, which are also consistent with different coal seam present in the Borehole. The fire propagation model established based on combined geophysical data can be effectively used for mine hazard mitigation planning around the study area.

\section{Declarations}

\section{Acknowledgements:}

Authors are thankful to DST for funding through a project (SB/S4/ES-640/2012) on geotechnical characterization of Jharia coalfield area using geophysical techniques. The authors wish to thank the Director, IIT ISM and the Head, Department of Applied Geophysics, for their support in the present study.

\section{References}

Agarwal R, Singh D, Chauhan D S and Singh K P (2006) Detection of coalmine fires in the Jharia coal field using NOAA/AVHRR data; J. Geophys. Eng. 3: 212-218.

Athanasiou E N, Tsourlos P I, Papazachos C B and Tsokas G N (2007) Combined weighted inversion of electrical resistivity data arising from different array types. J. Appl. Geophys. 62: 124-140.

Bartel L C (1982) Evaluation of the CSAMT geophysical technique to map abandoned coal mine fires. Contract DE-AC04-76DP00789, Department of Energy, Sandia National Laboratories, Albuquerque, New Mexico, U.S.A. In Proceeding of the $52^{\text {nd }}$ Annual International Meeting of the Society of Exploration Geophysicists, Dallas, Texas, U.S.A. 419-421.

Bharti A K, Pal S K and Vaish J (2014) Application of Self-potential method for coal fire detection over Jharia Coal field; 51 st Annual Convention of Indian Geophysical Union, Kurukshetra University, Kurukshetra, 19-21 November, 59-62.

Bharti A K, Pal S K, Priyam P, Kumar S, Shalivahan, Yadav P K (2016a) Subsurface cavity detection over Patherdih colliery, Jharia Coalfield, India using electrical resistivity tomography; Environ. Earth Sci. 75 (5) 1-17.

Bharti A K, Pal S K, Priyam P, Pathak V K, Kumar R and Ranjan S K (2016b) Detection of illegal mine voids using electrical resistivity tomography: the case-study of Raniganj coalfield (India); Eng. Geol. 213: 120-132.

Bhattacharya A, Reddy S and Mukherjee T (1991) Multi-tier remote sensing data analysis for coal fire mapping in Jharia coal field of Bihar, India; Asian Conference on Remote Sensing, Singapore, $\quad 30$ October-5 November, 1 22-1-6. 
Bhattacharya B B and Shalivahan S (2016) Geoelectric Methods: Theory and Applicatio; McGraw Hill Education (735p).

Cardarelli E, Di Filippo G and Tuccinardi E (2006) Electrical resistivity tomography to detect buried cavities in Rome: a case study; Near Surface Geophysics 4:387-392.

Chandra D 1992 Jharia coalfields, Geological Society of India, Bangalore.

Chatterjee R S (2006) Coal fire mapping from satellite thermal IR data a case example in Jharia coalfield, Jharkand, India; ISPRS J. Photogramm. Rem. Sens. 60: 113-128.

CMPDIL, (1988) Compendium on updated and revised geology of Jharia Coalfields, Ranchi, Jharkhand, India.

Coal mine fire: Railways to close section in Jharkhand,2017 http://www.newindianexpress.com/nation/2017/jun/12/coal-mine-fire-railways-to-close-section-injharkhand-1615847.html/ (accessed 12.06.17).

COP21 summit in Paris, 2015 The effects of coal fire and associated carbon emissions .http://www.cnbc.com/2015/12/02/(accessed10.10.2016).

Dahlin T and Zhou B (2004) A numerical comparison of 2D resistivity imaging with ten electrode arrays; Geophys. Prospect. 52: 379-398.

Dahlin T and Zhou B (2006) Multiple-gradient array measurements for multichannel 2D resistivity imaging ; Near Surface Geophysics 4: 113-123.

Dai S, Ren D, Chou C L, Finkelman R B, Seredin V V and Zhou Y (2012) Geochemistry of trace elements in Chinese coals: a review of abundances, genetic types, impacts on human health, and industrial utilization; Int. J. Coal Geol. 94: 3-21.

De la Vega M, Osella A and Lascano E (2003) Joint inversion of Wenner and dipole-dipole data to study a gasoline-contaminated soil ; J. Appl. Geophys. 54: 97-109.

Duba A (1977) Electrical conductivity of coal and coal char; Fuel 56: 441-443.

Duba A (1983) Electrical conductivity of Colorado oil shale to $900{ }^{\circ} \mathrm{C}$; Fuel 62: 966-972.

Engle M A, Radke, L F, Heffern E L, O'Keefe J M K, Hower J C, Smeltzer C D, Hower J M, Prakash A, Kolker A, Eatwell R J, Schure A, Queen G, Aggen K L, Stracher G B, Henke K R, Olea R A and Colón Y R 2011 Quantifying greenhouse gas emissions from coal fires using airborne and ground-based methods; Int. J. Coal Geol. 88: 147-51.

Ezersky M (2008) Geoelectric structure of the Ein Gedi sinkhole occurrence site at the Dead Sea shore in Israel; J. Appl. Geophys. 64: 56-69. 
Fox C S (1930) The Jharia coalfields, Geological Survey of India, Bangalore. 56.

Gautam, P. K., Biswas, A., (2016) 2D Geo-electrical imaging for shallow depth investigation in Doon Valley Sub-Himalaya, Uttarakhand, India; Modeling Earth Systems and Environment, 2(4): 175.

Gürdal G, Hoşgörmez H, Özcan, D, Li X, Liu H and Song W (2015) The properties of Çan Basin coals (Çanakkale Turkey): Spontaneous combustion and combustion by products; Int. J. Coal Geol. 138: $1-15$.

Gundelach V (2010) Contributions to the exploration of coal seam fires in China with ground penetrating radar. In: Drebenstedt, C., Fischer, C., Meyer, U., Wu, J., Kong, B. (Eds.), Latest Developments in Coal Fire Research-Bridging the Science, Economics, and Politics of a Global Disaster, Berlin, 9398.

Ide T S, Crook N and Orr F M (2011) Magnetometer measurements to characterize a subsurface coal fire; Int. J. Coal Geol. 87: 190-196.

Ide T S and Orr F M (2011) Comparison of methods to estimate the rate of $\mathrm{CO}_{2}$ emissions and coal consumption from a coal fire near Durango, CO; Int. J. Coal Geol. 86 5-107.

India douses century-old coal fires as Modi seeks output boost (2015) http://in.reuters.com/article/indiacoal-mines-modi-idINKBN0OG01R20150531/(accessed 12.10.16).

Karaoulis M, Revil A and Mao D (2014) Localization of a coal seam fire using combined self-potential and resistivity data; Int. J. Coal Geol. 128: 109-118.

King A (1987) Cindered coal detection using transient electromagnetic methods; Geoexploration,. 4 : 367 379.

Kuenzer C, Zhang J, Li J, Voigt S, Mehl H and Wagner W (2007a) Detection of unknown coal fires: synergy of coal fire risk area delineation and improved thermal anomaly extraction; Int. J.

Remote Sens. 28: 4561-4585.

Kuenzer C, Zhang J, Tetzlaff A, Voigt S, Van Dijk P, Wagner W and Mehl H (2007b) Uncontrolled coal fires and their environmental impacts: investigating two arid mining environments in north- central China; Appl. Geogr. 27: 42-62.

Kuenzer C, Zhang J, Hirner A, Bo Y, Jia Y and Sun Y (2008) Multitemporal insitu mapping of the Wuda coal fires from 2000 to 2005 - assessing coal fire dynamics. UNESCO Beijing, 2008, Spontaneous Coal Seam Fires: Mitigating a Global Disaster: ERSEC ecological book series, $4 . \quad$ pp. 132-148.

Kuenzer C, Zhang J, Sun Y, Jia Y and Dech S (2012) Coal fires revisited: The Wuda coal field in the aftermath of extensive coal fire research and accelerating extinguishing activities; Int. J.Coal Geol. 102: 75-86. 
Kumar S, Pal S K, Vaish J and Shalivahan S (2015) Utilization of magnetic gradient method for coal fire mapping of Chatabad area, a part of Jharia Coal field, India; J. Eng. Geol. Special Publication 170-176.

Litschke T, Wiegand J, Schloemer S, Gielisch H and Bandelow F K (2008) Detailed mapping of coal fires in combination with in-situ gas flow measurements to estimate Mass flow balance and fire development. Spontaneous Coal Seam Fires: Mitigating a Global Disaster ERSEC Ecological Book Series vol. 4. UNESCO, Beijing. ISBN: 978-7-302-17140-9, 306-333.

Loke M H (2004) Tutorial: 2-D and 3-D Electrical Imaging Surveys 128.

Loke M H, Chambers J E, Rucker D F, Kuras 0 and Wilkinson P B 2013 Recent developments in the direct-current geoelectrical imaging method; J. Appl. Geophys. 95 :135-156.

Mishra R K, Roy P N S, Singh V K, and Pandey J K 2018 Detection and delineation of coal mine fire in Jharia coal field, India using geophysical approach: A case study; J. Earth Syst. Sci. 127: 107.

Mishra R K, Bahuguna P P and Singh V K 2011 Detection of coal mine fire in Jharia coal field using Landsat-7 ETM+ data; Int. J. Coal Geol. 86 73-78.

Michalski S R 2004 The Jharia fire control technical assistance project an analysis; Int. J. Coal Geol. 59 $83-90$.

Northrop D 1975 Instrumentation and process control development for in situ coal gasification, in Second Quarterly Report: March Through May 1975, Sandia Labs., Albuquerque, N. Mex. (USA).

Pal S K, Vaish J, Kumar S and Bharti A K (2016) Coalfire mapping of East Basuria Colliery, Jharia coal field using Vertical Derivative Technique of Magnetic data; J. Earth Syst. Sci. 125(1): 165178.

Pal S K, Vaish J, Kumar S, Priyam P, Bharti A K and Kumar R (2017) Downward continuation and Tilt Derivative of magnetic data for delineation of concealed coal fire in East Basuria Colliery, Jharia coal field, India; J. Earth Syst. Sci. 126(53) : 1-17.

Powell R W and Schofield F H (1939) The thermal and electrical conductivities of carbon and graphite to high temperatures; Proc. Phys. Soc. 51: 153. http://dx.doi.org/10.1088/09595309/51/1/317

Prakash A, Saraf A K, Gupta R P and Sundaram R M (1995) Surface thermal anomalies associated with underground fires in Jharia coal mines, India; Int. J. Remote Sens. 16: 2105-2109.

Prakash A, Gupta R P and Saraf A K (1997) A Landsat TM based comparative study of surface and subsurface fire in the Jharia Coal Field, India; Int. J. Remote Sens. 18 (11): 2463-2469. 
Prakash A and Gupta R P (1998) Reflection aureoles associated with thermal anomalies due to subsurface mine fires in the Jharia Coalfield, India; Int. J. Remote Sens. 19 : 2619-2622.

Prakash A and Gupta R P (1999) Land-use mapping and change detection in a coal mining area: a case study in the Jharia coalfield, India; Int. J. Remote Sens. 19: 391-410.

Rehabilitation and resettlement of the people due to coal fire 2016 http://timesofindia.indiatimes.com/city/kolkata/.(accessed 12.02.16).

Reid A B, Allsop J M, Granser H, Millett A J and Somerton I W (1990) Magnetic interpretation in three dimensions using Euler deconvolution; Geophysics 55: 80-91.

Revil A, Karaoulis M, Srivastava S and Byrdina S (2013) Thermoelectric self-potential and resistivity data localize the burning front of underground coal fires; Geophysics 78(5): B259-B273

Revil A and Jardani A (2013) The Self-Potential Method: Theory and Applications in Environmental Geosciences; Cambridge University Press pp.367.

Rodriguez B D (1983) A self-potential investigation of a coal mine fire; MS Thesis, Colorado School of Mines, 132p.

Saraf A K, Prakash A, Sengupta S and Gupta R P (1995) Landsat-TM data for estimating ground temperature and depth of subsurface coalfire in the Jharia coalfield, India; Int. J. Rem. Sens. 16 : 2111-2124.

Schaumann G, Siemon B and Changchun Y (2008) Geophysical investigation of Wuda coal mining area, Inner Mongolia: electromagnetics and magnetics for coal fire detection. Spontaneous Coal Seam Fires: Mitigating a Global DisasterERSEC Ecological Book Series vol. 4. UNESCO, Beijing. ISBN: 978-7-302-17140-9, pp. 336-349.

Schloemer S (2006) Innovative Technologies for Exploration, Extinction and Monitoring of Coal Fires in North China, Final Report on Gas and Temperature Measurements at Fire Zones. Federal Institute for Geosciences and Natural Resources (BGR), D - 30655 Hannover, Germany, pp.1- 53.

Schloemer S, Teschner M, Poggenburg J and Seeger C (2008) Gas and temperature monitoring of a spontaneous coal seam fire in Wuda coal mining area. Spontaneous CoalSeam Fires: Mitigating a Global Disaster ERSEC Ecological Book Series vol. 4. UNESCO,Beijing. ISBN: 978- 7-302-17140-9, pp. 277-304.

Sengupta N (1980) A revision of the Geology of the Jharia Coalfield with particular reference to distribution of coal seams, Ph.D. Thesis, Indian School of Mines, Dhanbad.

Shao Z, Wang D, Wang Yand Zhong X 2014 Theory and application of magnetic and self-potential methods in the detection of the Heshituoluogai coal fire, China; J. Appl.Geophys. 104 : 64-74. 
Shao Z, Wang D, Wang Y, Zhong X, Tang X and Xi D (2016) Electrical resistivity of coal-bearing rocks under high temperature and the detection of coal fires using electrical resistance tomography; Geophys. J. int. 204 :1316-1331.

Singh R and Pal S K (2015) In: Detection of coal fire zone in Patherdih Colliery, Dhanbad using magnetic modelling; 52nd Annual Convention of Indian Geophysical Union, NCAOR, Goa, 3-5 November.

Singh P., Pal S.K. and Kumar S. (2019) Inversion of Self Potential Anomaly for Coal Seam Fire Prediction Using Genetic Algorithm. 81st EAGE Conference and Exhibition 2019, Jun 2019, Volume 2019, p.1 - 5, https://doi.org/10.3997/2214-4609.201901125

Singh, B.B.; Srivardhan, V.; Pal, S.K. ; Kanagaraju, S.K.; Kumar S. and Vaish J., (2015) Particle Swarm Optimization Inversion of Self Potential Anomaly for Detecting Coal Fires, a Case Study - Jharia Coal Field. Third Sustainable Earth and Sciences conference in Celle, Germany, EAGE, DOI: 10.3997/22144609.201414282

Srivardhan V, Pal S K, Vaish J, Kumar S, Bharti A K and Priyam P (2016) Particle swarm optimization inversion of self -potential data for depth estimation of coal fires over East Basuria colliery, Jharia coal field, India; Environ. Earth Sci. 75(8): 1-12. http://dx.doi.org/10.1007/s12665-015-5222-9.

Song Z and Kuenzer C (2014) Coal fires in China over the last decade: A comprehensive review; Int. J. Coal Geol. $133: 72-99$.

Srivastava S., Pal S K and Kumar Rajwardhan, (2020) A time-lapse study using Self-Potential and Electrical Resistivity Tomography methods for mapping of old mine working across railway-tracks in a part of Raniganj Coalfield, India. Environmental Earth Sciences, 79:332. https://doi.org/10.1007/s12665020-09067-3

Stracher G B (2004) Coal fires burning around the world: a global catastrophe; Int. J. Coal Geology 59 :16.

Stracher G B 2010 Coal fires: The Rising Global Interest; EARTH 55(9) 46-55. http:// www.earthmagazine.org/earth/article/383-7da-9-1.

Stummer P, Maurer $\mathrm{H}$ and Green A (2004) Experimental design: electrical resistivity data sets that provide optimum subsurface information; Geophysics 69: 120-139.

Vaish J and Pal S K (2013) Interpretation of Magnetic Anomaly data over East Basuria region using an Enhanced Local Wavenumber (ELW) Technique; 10th Biennial International Conference and Exposition on Petroleum Geophysics, Kochi, 23 - 25 November, P110.

Vaish J and Pal S K (2015) Subsurface coal fire mapping of East Basuria Colliery, Jharkhand; J. Geol. Soci. India 86(4): 438-444.http://dx.doi.org/ 10.1007/s12594-015-0331-3 
Vaish J and Pal S K (2016) Subsurface Coal fire mapping of Patherdih Colliery a part of Jharia coal field, India; J. Geol. Soci. India.

Xie J, Xue S, Cheng W and Wang G (2011) Early detection of spontaneous combustion of coal in underground coal mines with development of an ethylene enriching system; Int. J. Coal Geol. 127.

Zhang X, Xu J, Xi G, Deng J and Wen H (2008) Model and control of high temperaturecoal fires. Spontaneous Coal Seam Fires: Mitigating a Global DisasterERSEC Ecological Book Series vol. 4. UNESCO, Beijing. ISBN: 978-7-302-17140-9, pp. 544-553.

Zhe J S, Greenhalgh S A and Marescot L (2007) Multichannel, full waveform and flexible electrode combination resistivity-imaging system; Geophysics 72(2):57-64. 10.1190/1.2435081

Zhou B and Greenhalgh S A (1999) Explicit expressions and numerical calculations for the Frechet and second derivatives in 2.5D Helmholtz equation inversion; Geophys.Prospect. 47: 443-468.

Zhou B and Greenhalgh S A (2000) Crosshole resistivity tomography using different electrode configurations; Geophys. Prospect. 48 :887-912.

Zhou B and Greenhalgh S A (2001) Finite element three-dimensional direct current resistivity modelling: accuracy and efficiency considerations; Geophys. J. Int. 145: 676-688.

\section{Tables}

Table1. Details of distinct resistive anomalous features delineated along AA' profile using (a) Wenner, (b) Schlumberger, (c) Dipole-Dipole (d) Gradient, arrays and (e) Combined inversion of all the arrays 


\begin{tabular}{|c|c|c|c|c|c|}
\hline $\begin{array}{l}\text { 2D ERT } \\
\text { section }\end{array}$ & $\begin{array}{l}\text { Subsurfa } \\
\text { ce } \\
\text { Features }\end{array}$ & $\begin{array}{l}\text { Approx. Centre of } \\
\text { anomaly Reduced } \\
\text { distance } \\
\text { (RD in } \mathrm{m} \text { ) }\end{array}$ & $\begin{array}{l}\text { Approx. } \\
\text { Anomaly } \\
\text { Depth (m) }\end{array}$ & $\begin{array}{l}\text { Approx. } \\
\text { Inverted } \\
\text { resistivity }(\Omega m)\end{array}$ & $\begin{array}{l}\text { Possible } \\
\text { attributes }\end{array}$ \\
\hline \multirow{3}{*}{ Wenner } & 1 & 50 & 20 & 10 & Coal fires \\
\hline & 2 & 153 & 28 & 80 & Coal fires \\
\hline & 3 & 246 & 24 & 320 & $\begin{array}{l}\text { Burned } \\
\text { coal and } \\
\text { void }\end{array}$ \\
\hline \multirow{3}{*}{ Schlumberger } & 1 & 40 & 22 & 40 & Coal fires \\
\hline & 2 & 149 & 44 & 60 & Coal fires \\
\hline & 3 & 245 & 29 & 476 & $\begin{array}{l}\text { Burned } \\
\text { coal and } \\
\text { void }\end{array}$ \\
\hline \multirow[t]{2}{*}{ Dipole-Dipole } & 1 & 63 & 15 & 20 & Coal fires \\
\hline & 3 & 250 & 20 & 383 & $\begin{array}{l}\text { Burned } \\
\text { coal and } \\
\text { void }\end{array}$ \\
\hline \multirow{3}{*}{ Gradient } & 1 & 54 & 16 & 20 & Coal fires \\
\hline & 2 & 147 & 37 & 20 & Coal fires \\
\hline & 3 & 232 & 33 & 438 & $\begin{array}{l}\text { Burned } \\
\text { coal and } \\
\text { void }\end{array}$ \\
\hline \multirow{3}{*}{$\begin{array}{l}\text { Joint } \\
\text { inversion }\end{array}$} & 1 & 50 & 25 & 20 & Coal fires \\
\hline & 2 & 160 & 35 & 10 & Coal fires \\
\hline & 3 & 240 & 35 & 500 & $\begin{array}{l}\text { Burned } \\
\text { coal and } \\
\text { void }\end{array}$ \\
\hline
\end{tabular}

Table2. Details of distinct resistive anomalous features delineated in BB' profile using (a) Wenner, (b) Schlumberger, (c) Dipole-Dipole, (d) Gradient arrays and (e) Combined inversion of all the arrays 


\begin{tabular}{|llllll|}
\hline $\begin{array}{l}\text { 2D ERT } \\
\text { section }\end{array}$ & $\begin{array}{l}\text { Subsurface } \\
\text { Features }\end{array}$ & $\begin{array}{l}\text { Approx. Centre of } \\
\text { anomaly Reduced } \\
\text { distance } \\
\text { (RD in } \mathbf{m})\end{array}$ & $\begin{array}{l}\text { Approx. } \\
\text { Anomaly } \\
\text { Depth }(\mathbf{m})\end{array}$ & $\begin{array}{l}\text { Approx. } \\
\text { Inverted } \\
\text { resistivity } \\
(\mathbf{\Omega m})\end{array}$ & $\begin{array}{l}\text { Possible } \\
\text { attributes }\end{array}$ \\
\hline Wenner & 3 & 260 & 10 & 361 & $\begin{array}{l}\text { Burned } \\
\text { coal and } \\
\text { void }\end{array}$ \\
\hline Schlumberger & 3 & 254 & 10 & 513 & \\
\hline Dipole-Dipole & 3 & 259 & 10 & 420 & $\begin{array}{l}\text { Burned } \\
\text { coal and } \\
\text { void }\end{array}$ \\
\hline Gradient & 3 & 256 & 10 & 480 & Coal Fire \\
\hline $\begin{array}{l}\text { Joint } \\
\text { inversion }\end{array}$ & 1 & 75 & 42 & 320 & $\begin{array}{l}\text { Burned } \\
\text { coal and } \\
\text { void }\end{array}$ \\
\hline
\end{tabular}

Table3. Details of distinct resistive anomalous features delineated in $\mathrm{CC}^{\prime}$ profile using (a) Wenner, (b) Schlumberger, (c) Dipole-Dipole (d)Gradient, arrays and (e) Combined inversion of all the arrays 


\begin{tabular}{|c|c|c|c|c|c|}
\hline $\begin{array}{l}\text { 2D ERT } \\
\text { section }\end{array}$ & $\begin{array}{l}\text { Subsurface } \\
\text { Features }\end{array}$ & $\begin{array}{l}\text { Approx. Centre of } \\
\text { anomaly Reduced } \\
\text { distance } \\
\text { (RD in } \mathrm{m} \text { ) }\end{array}$ & $\begin{array}{l}\text { Approx. } \\
\text { Anomaly } \\
\text { Depth (m) }\end{array}$ & $\begin{array}{l}\text { Approx. } \\
\text { Inverted } \\
\text { resistivity } \\
(\Omega \mathrm{m})\end{array}$ & $\begin{array}{l}\text { Possible } \\
\text { attributes }\end{array}$ \\
\hline \multirow{3}{*}{ Wenner } & 1 & 58 & 18 & 200 & $\begin{array}{l}\text { Burned } \\
\text { coal }\end{array}$ \\
\hline & 2 & 151 & 24 & 60 & Coal fire \\
\hline & 3 & 195 & 28 & 375 & $\begin{array}{l}\text { Burned } \\
\text { coal and } \\
\text { void }\end{array}$ \\
\hline \multirow{3}{*}{ Schlumberger } & 1 & 65 & 18 & 250 & $\begin{array}{l}\text { Burned } \\
\text { coal }\end{array}$ \\
\hline & 2 & 153 & 45 & 47 & Coal fire \\
\hline & 3 & 210 & 31 & 325 & \multirow{2}{*}{$\begin{array}{l}\text { Burned } \\
\text { coal and } \\
\text { void }\end{array}$} \\
\hline Dipole-Dipole & 3 & 201 & 16 & 285 & \\
\hline \multirow[b]{2}{*}{ Gradient } & 1 & 34 & 16 & 4 & Coal fire \\
\hline & 3 & 236 & 33 & 595 & \multirow{2}{*}{$\begin{array}{l}\text { Burned } \\
\text { coal and } \\
\text { void }\end{array}$} \\
\hline \multirow{3}{*}{$\begin{array}{l}\text { Joint } \\
\text { inversion }\end{array}$} & 1 & 50 & 25 & 300 & \\
\hline & 2 & 145 & 30 & 10 & Coal fire \\
\hline & 3 & 220 & 35 & 400 & $\begin{array}{l}\text { Burned } \\
\text { coal and } \\
\text { void }\end{array}$ \\
\hline
\end{tabular}

Figures 


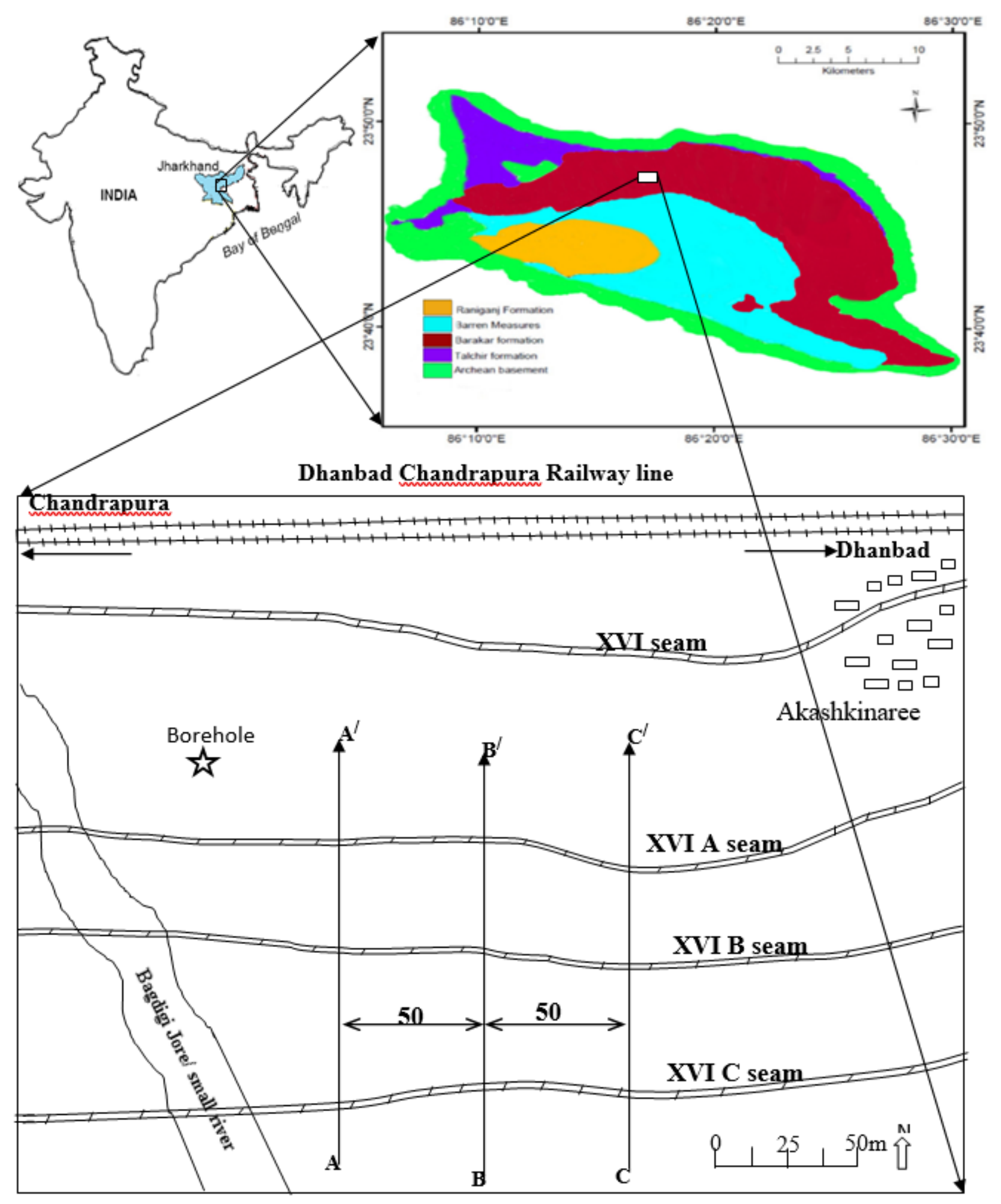

Figure 1

(a). Location map of the study area along with a generalized geological map of Jharia Coalfield (b) Schematic location plan showing survey line in the study area, Akashkinaree Colliery, Jharia Coalfield, India. Note: The designations employed and the presentation of the material on this map do not imply the expression of any opinion whatsoever on the part of Research Square concerning the legal status of any 
country, territory, city or area or of its authorities, or concerning the delimitation of its frontiers or boundaries. This map has been provided by the authors.

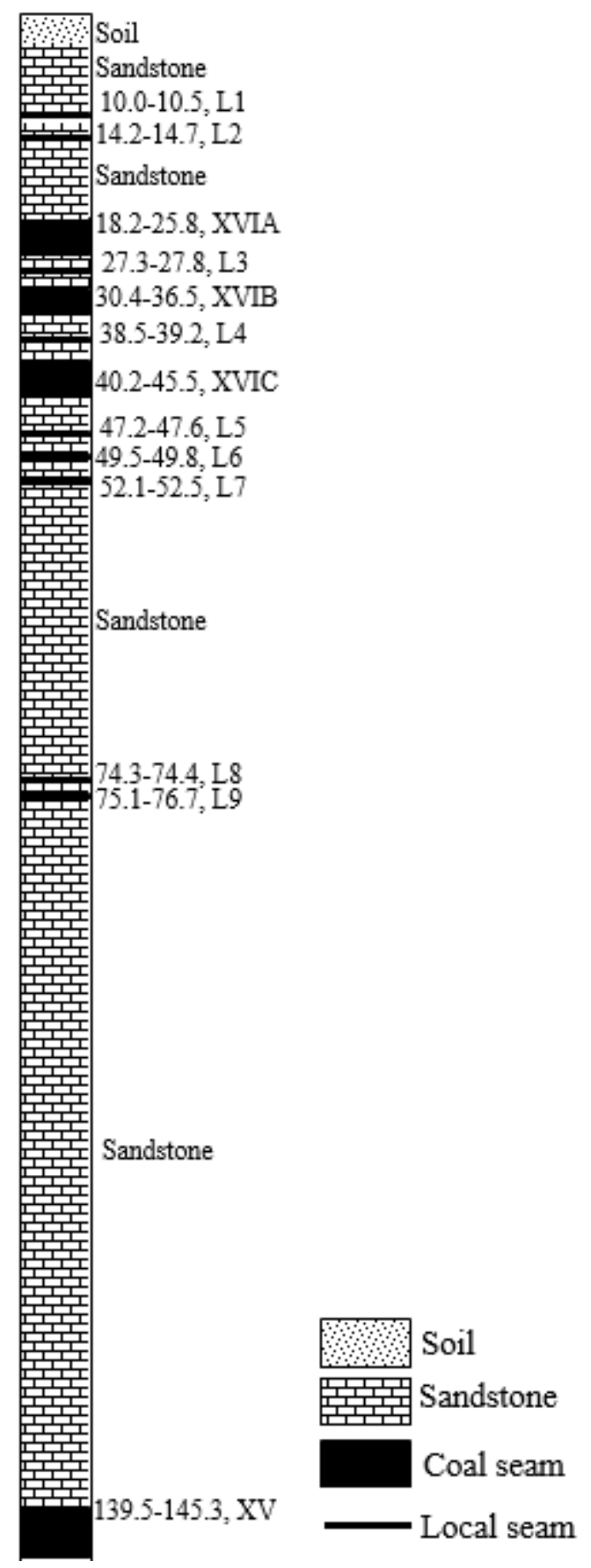

Figure 2

Borehole litholog showing different coal seams at different depths in meter. L1-L8 and XVI A,B,C are in fire. The location of this borehole is shown in Fig.1. 


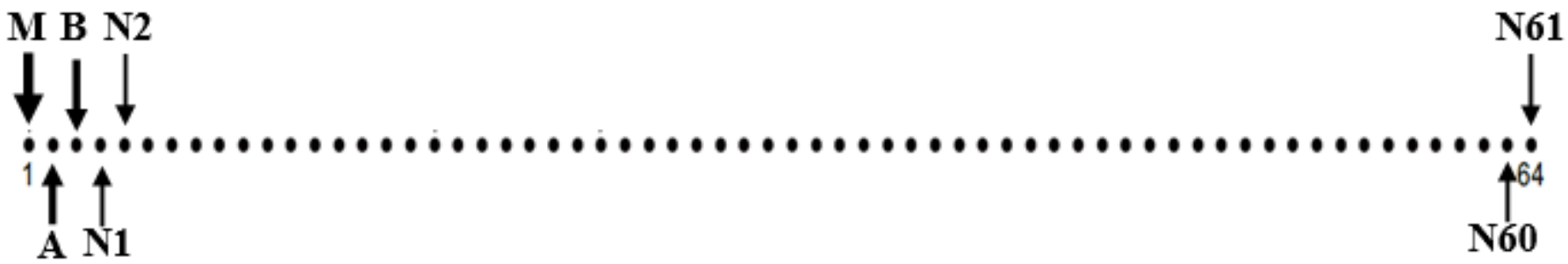

\section{Figure 3}

61 Channel ERT data-acquisition field setup using 64 electrodes, of which two as current electrodes(A and $B)$ and one as common reference electrode $(M)$ and 61 potentials reletave to $M$ on remaing electrodes. The choice of the reference electrode is dynamic (Zhe et al., 2007). 


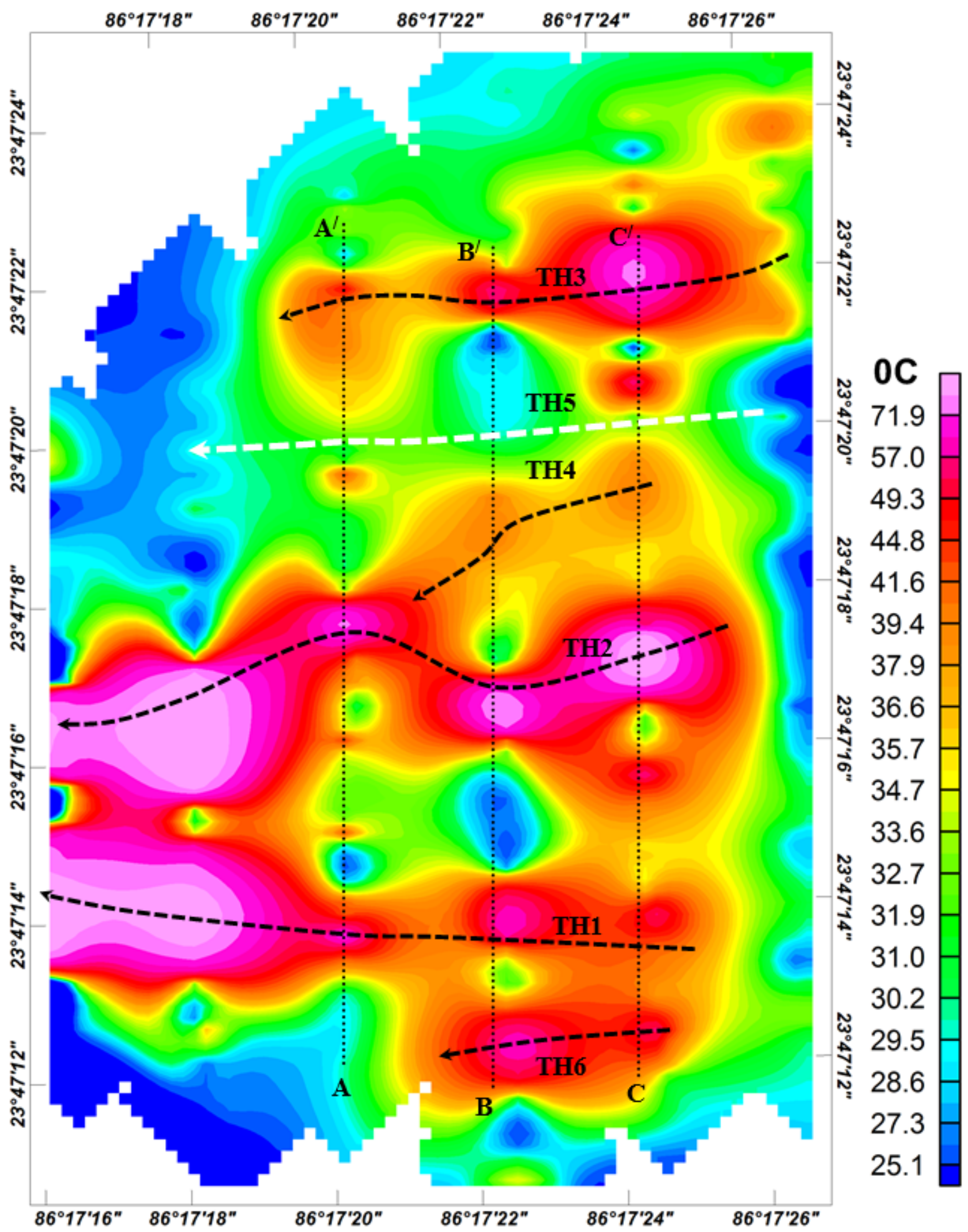

Figure 4

Surface temperature anomaly map showing three prominent high-temperature zones (TH1, TH2 and TH3) associated with fire in coal seam XVIC, XVIB and L1/L2, respectively. TH5 could be associated with burned and cooling of XVIA. Locations of ERT profiles (AA/, BB/ and CC/) are shown for correlation with ERT results. 

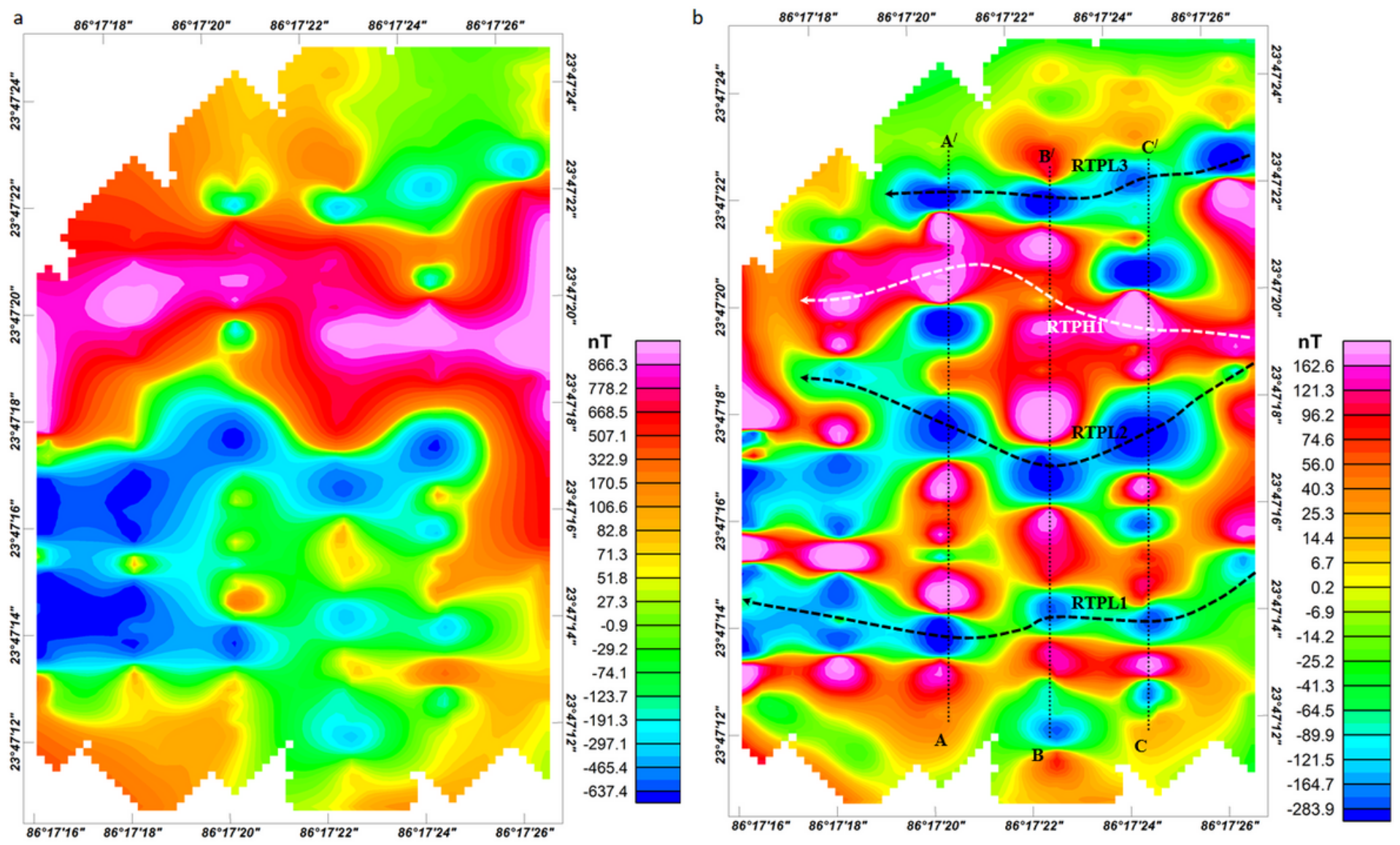

\section{Figure 5}

a Reduced north magnetic pole (RTP) anomaly map. b Residual anomaly map of RTP showing three prominent negative RTP anomaly zones (RTPL1, RTPL2 and RTPL3) associated with fire in coal seam $\mathrm{XVIC}, \mathrm{XVIB}$ and L1/L2, respectively. RTPH1 could be associated with burned and cooling of XVIA. Locations of ERT profiles (AA/, BB/ and CC/) are shown for correlation with ERT results. 

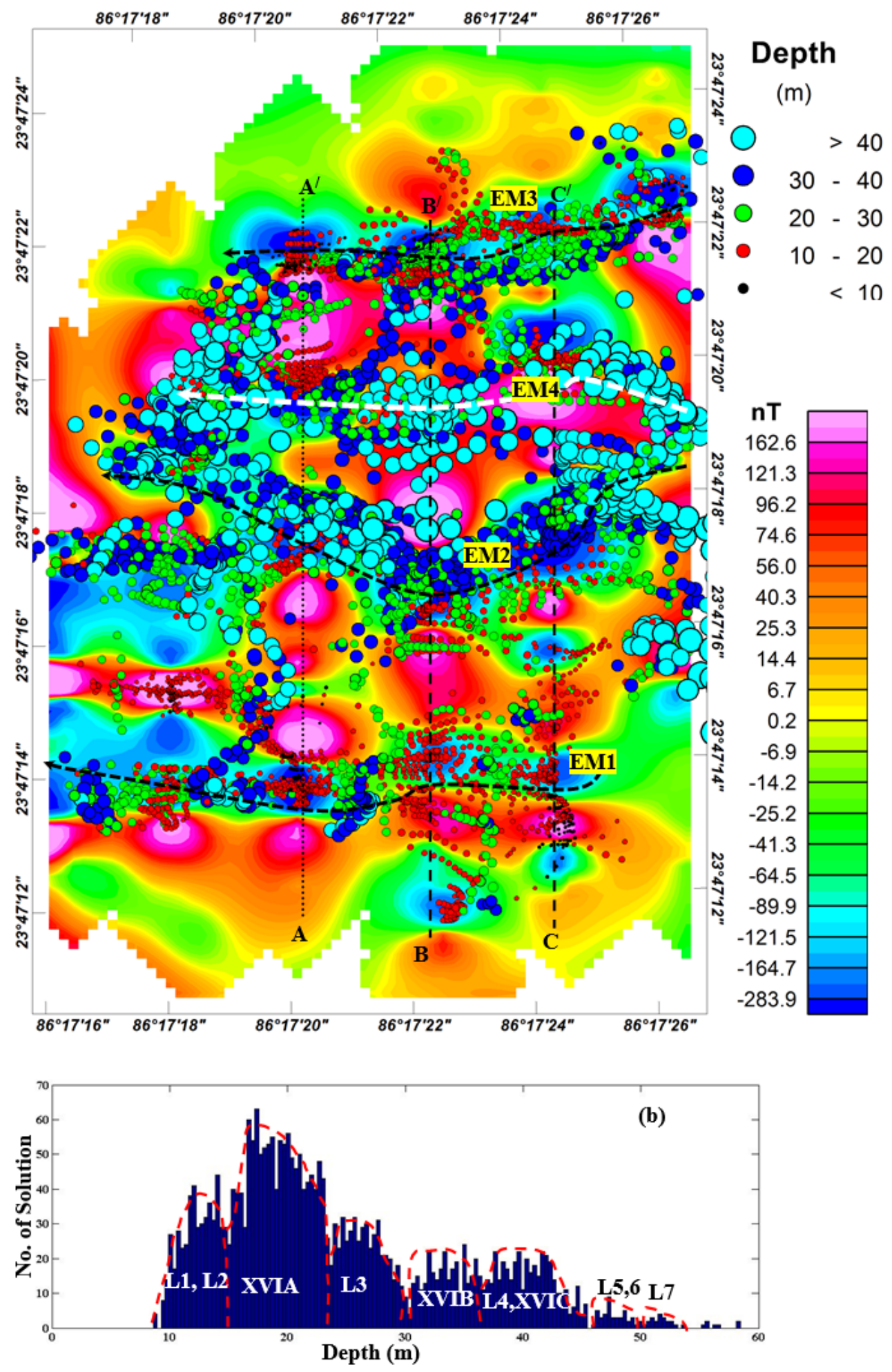

Figure 6

a The Euler's depth solutions estimated from RTP anomaly with $\mathrm{SI}=3.0$ overlain on residuals of RTP anomaly. Three prominent clustering pattern (EM1, EM2 and EM3) could be associated with fire in coal seam XVIC, XVIB and L1\&L2. EM4 could be associated with burned and cooling of XVIA. Locations of ERT profiles (AA/, BB/ and $\mathrm{CC} /$ ) are shown for correlation with ERT results. b Histograms of Euler's depth solutions of RTP anomaly 
Coal fire affected area

Coal fire affected Burned Coal seam and filled with

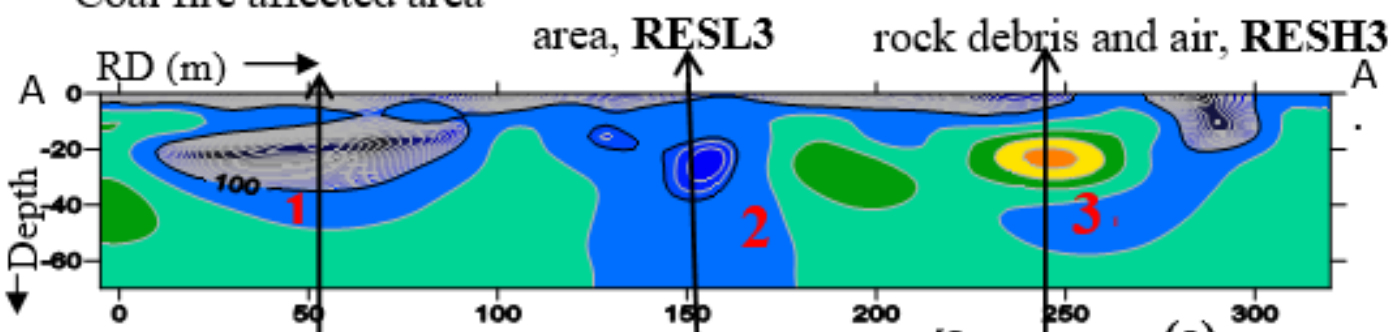

(a)
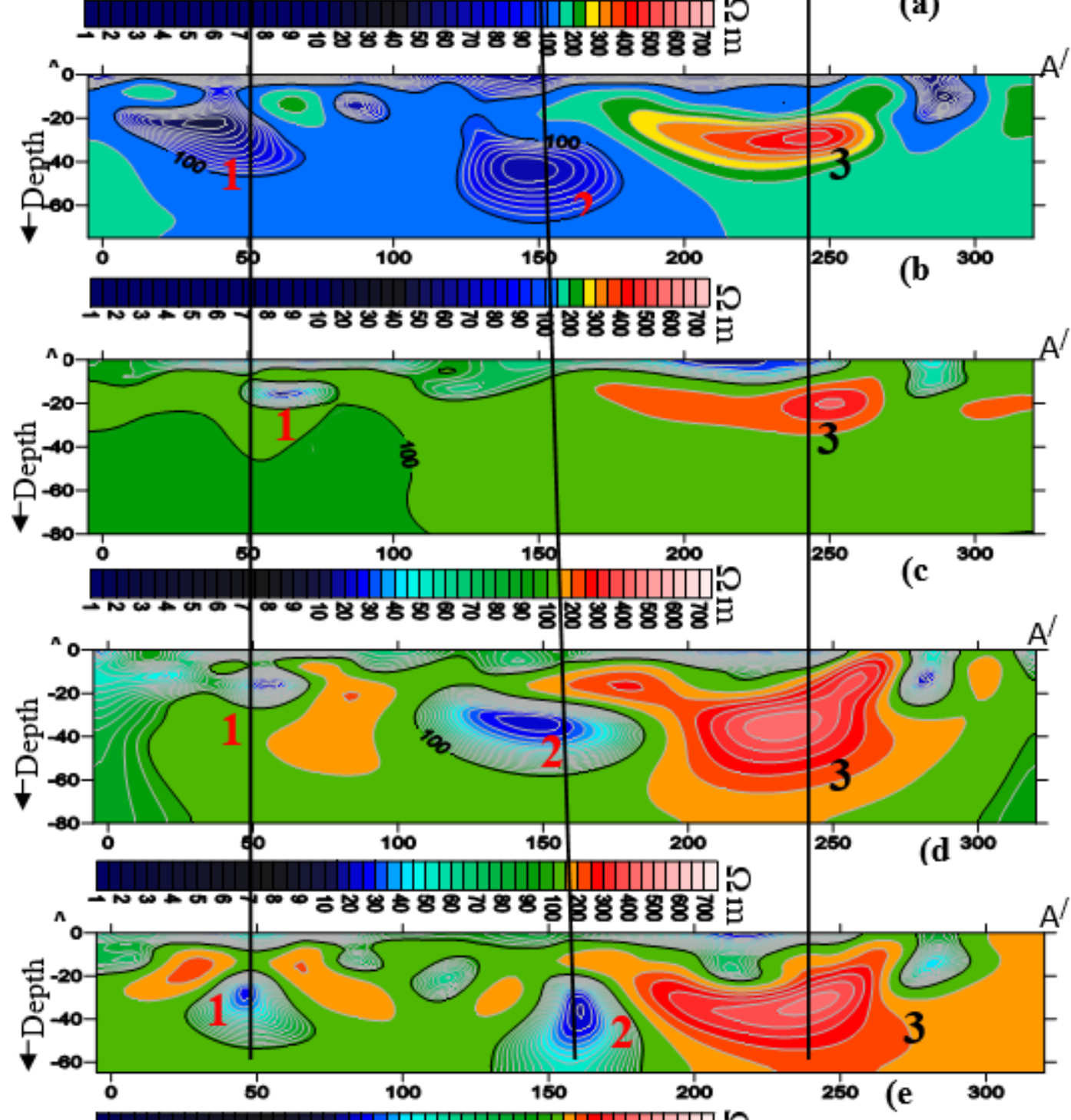

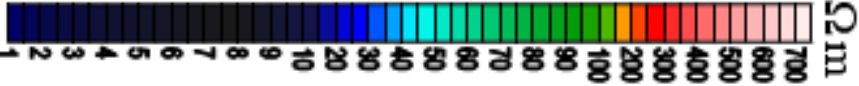

Figure 7

2D ERT section along AA/ generated using (a)Wenner, (b)Schlumberger, (c) Dipole-Dipole, (d) Gradient arrays and (e) Combined inversion of all the arrays with the current threshold of $100 \mathrm{~mA}$ and quality factor $5 \%$. 


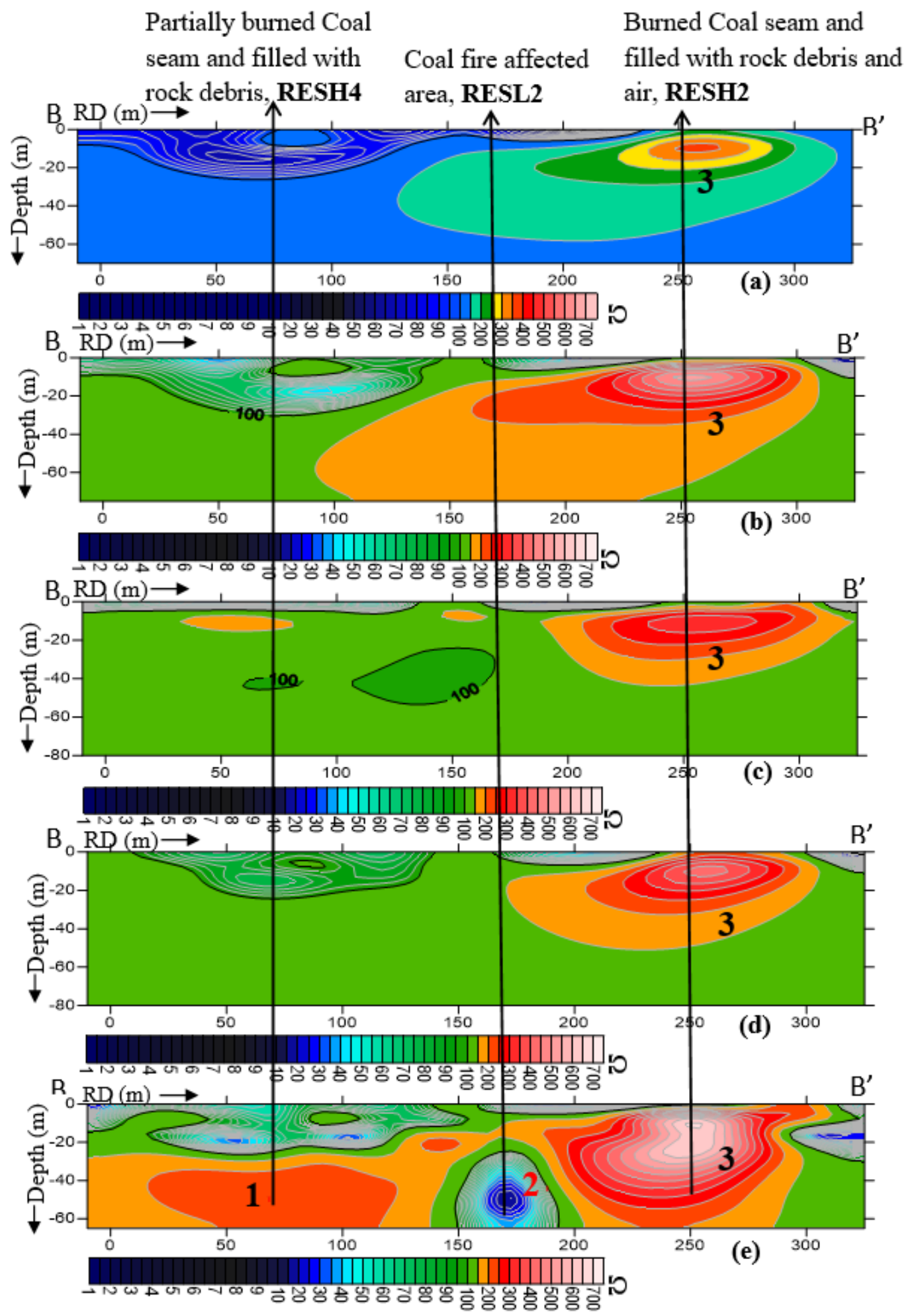

\section{Figure 8}

2D ERT section along BB/ generated using (a)Wenner, (b)Schlumberger, (c) Dipole-Dipole, (d) Gradient arrays and (e) Combined inversion of all the arrays with the current threshold of $100 \mathrm{~mA}$ and quality factor $5 \%$. 

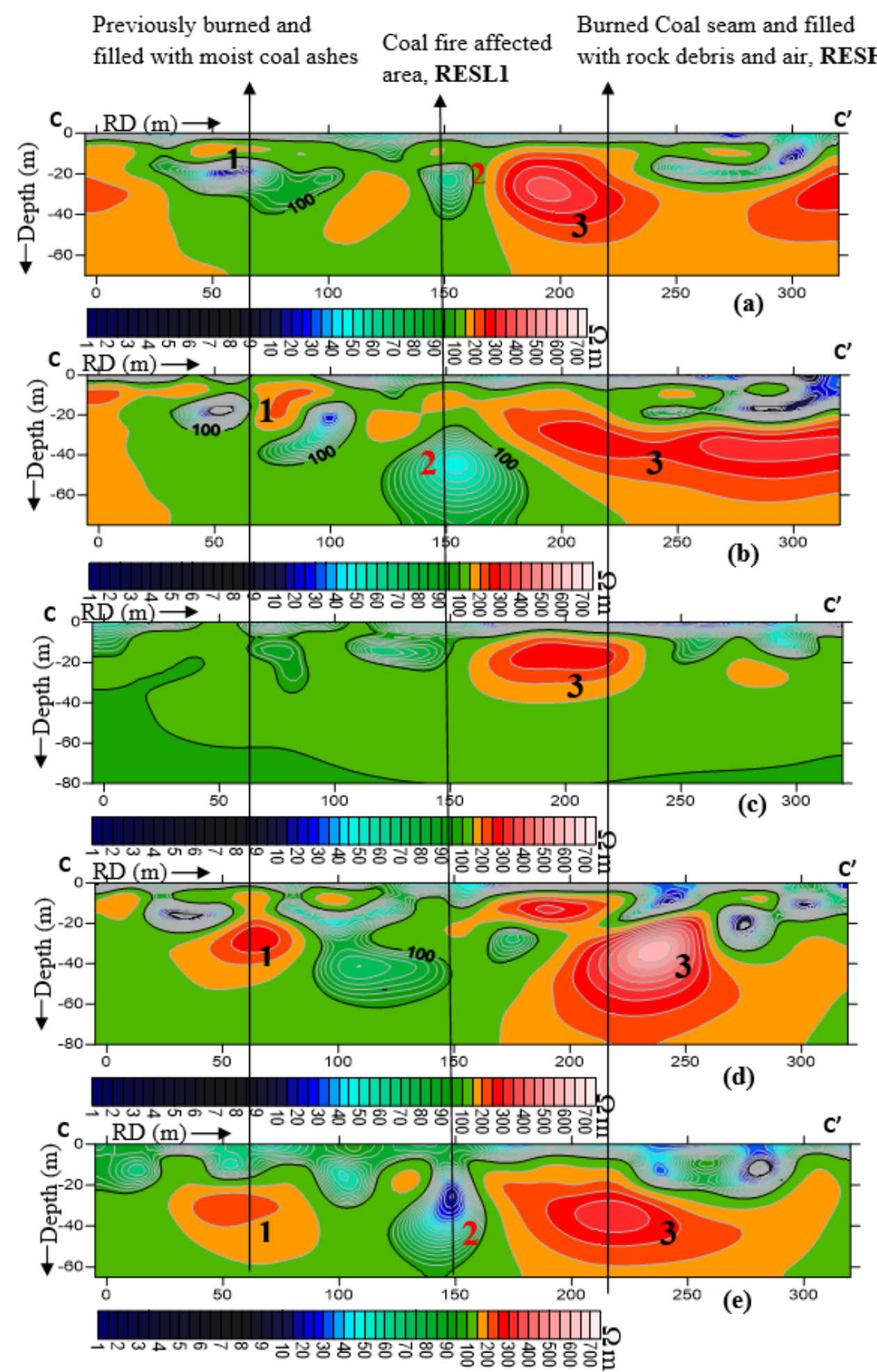

\section{Figure 9}

2D ERT section along CC/ generated using (a)Wenner, (b)Schlumberger, (c) Dipole-Dipole, (d) Gradient arrays and (e) Combined inversion of all the arrays with the current threshold of $100 \mathrm{~mA}$ and quality factor $5 \%$. 


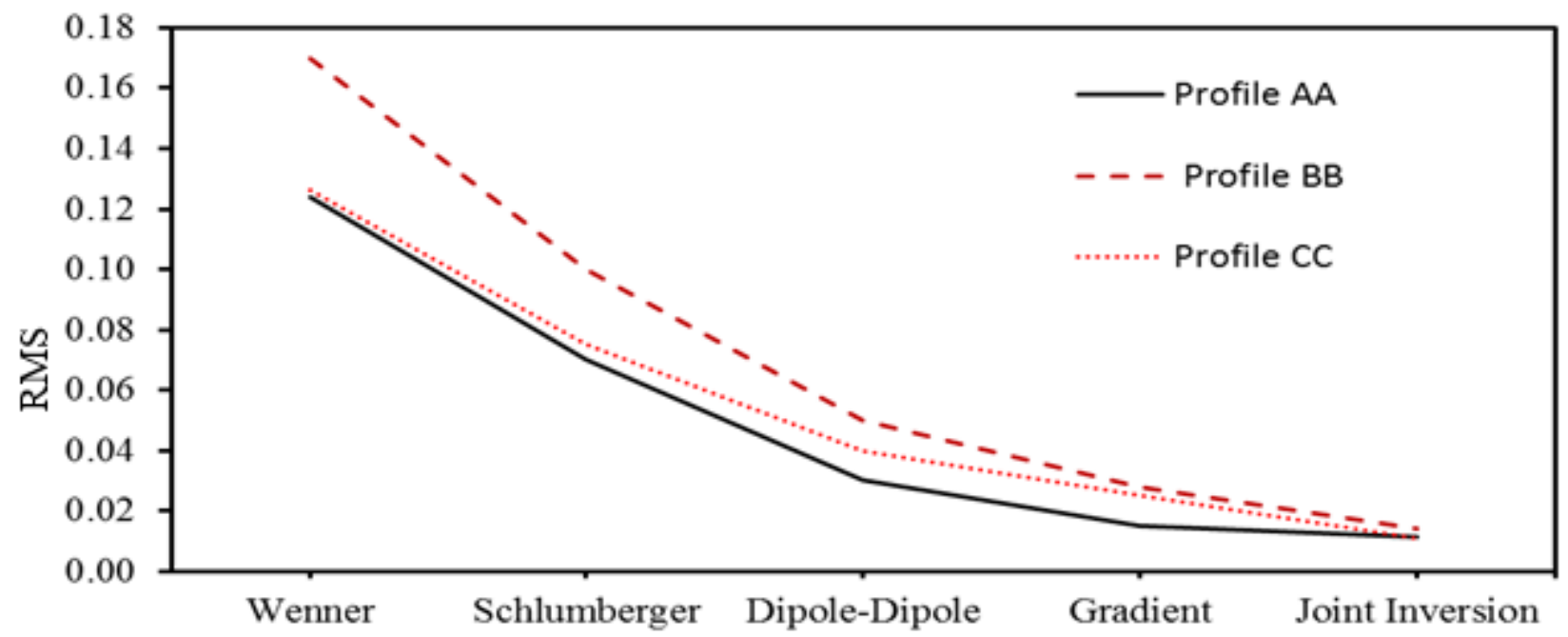

Figure 10

Graphical plot of root-mean-square(RMS) errors for the 2D inverted ERT sections of Wenner, Schlumberger, Dipole-Dipole, Gradient and combined inversion of all arrays for profiles AA/, BB/ and CC/. 

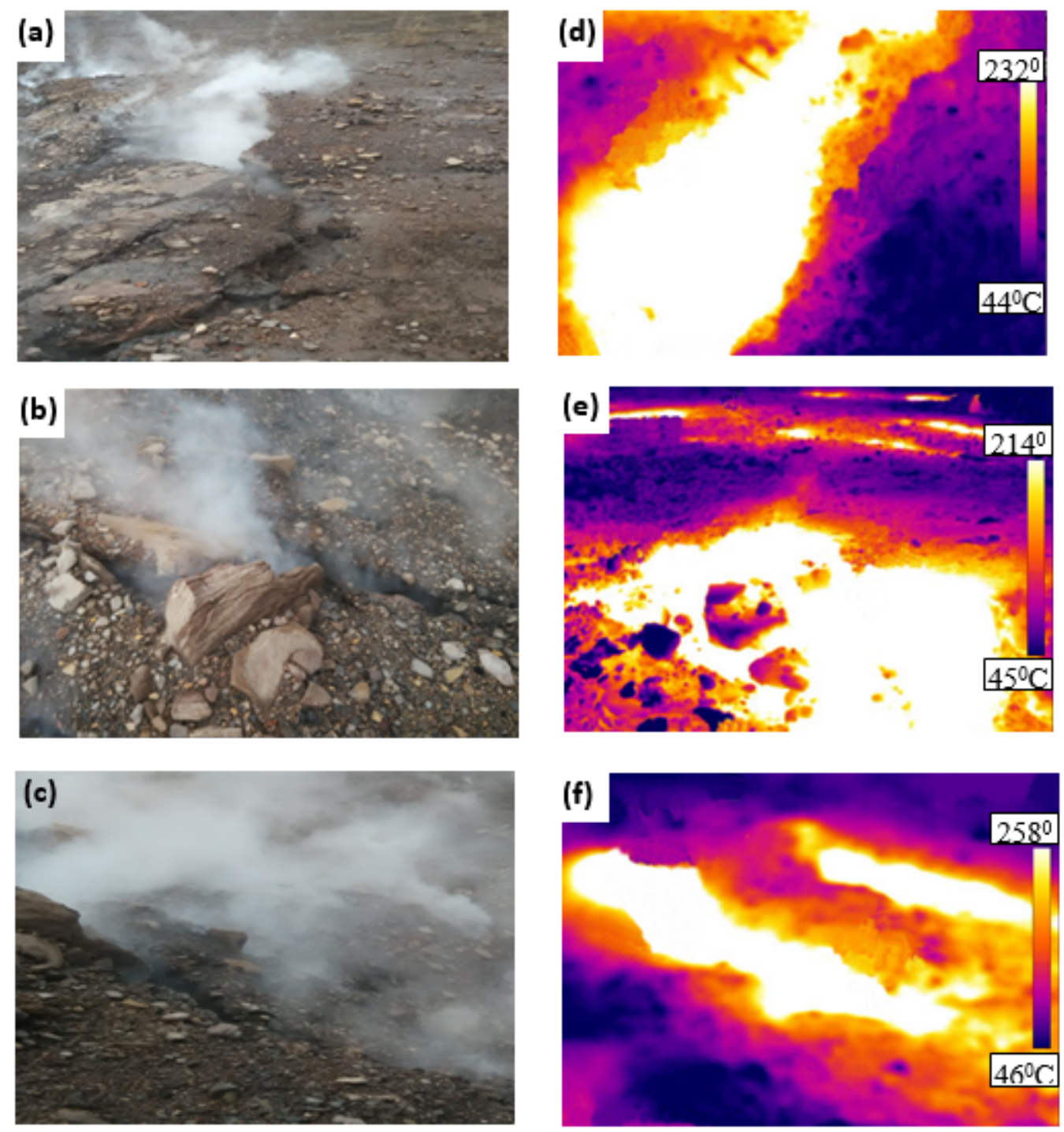

\section{Figure 11}

(a), (b), (c), are the field photographs over active fires through fissures, cracks, etc. The corresponding low resistivity anomalies have been delineated in the 2D ERT sections of profiles AA/, BB/ and CC/, as Res-L3, Res-L2, and Res-L1, respectively. (d), (e) and (f) are the respective thermal images. 

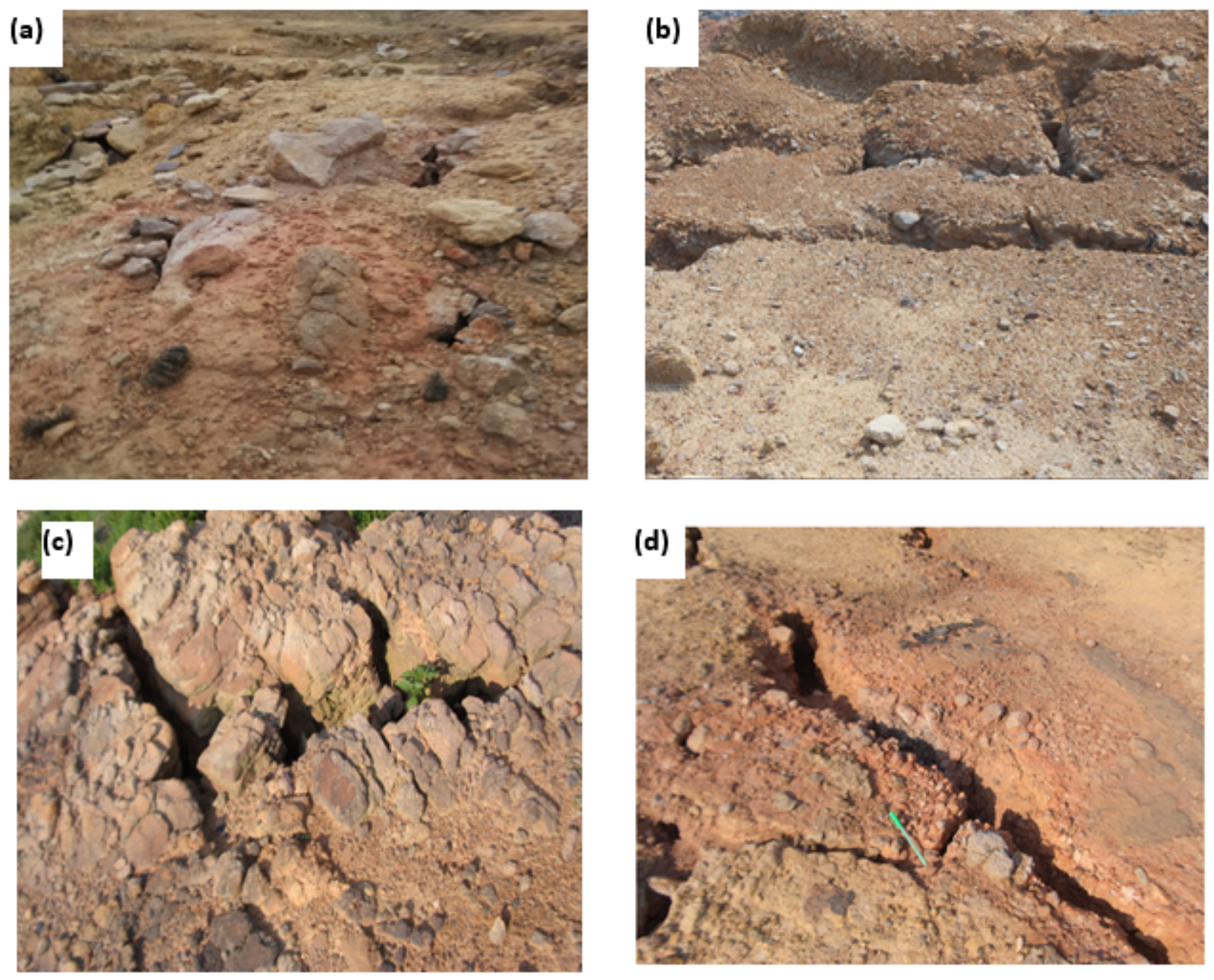

\section{Figure 12}

(a), (b), (c) (d), are field photographs showing numerous higher-order fractures/ cracks fissures, pothole etc. over previous coal fire-affected areas. The corresponding high resistivity anomalies have delineated in ERT sections as Res-H3 (AA/), Res-H2(BB/), Res-H1(CC/) and Res-H4 (BB/), respectively. 
Very low resistivities

Relatively high resistivities indicate void indicate formation generated in pyrolysis process due to active coal seam fire propagation caused by $\mathrm{O}_{2}$ circulation formation caused by volume reduction due to the transformation of coal to char and further to ashes mixed with surrounding rock debris. The char and associated volatiles get burned due to high $\mathrm{O}_{2}$ circulation through numerous primary and secondary fractures which results

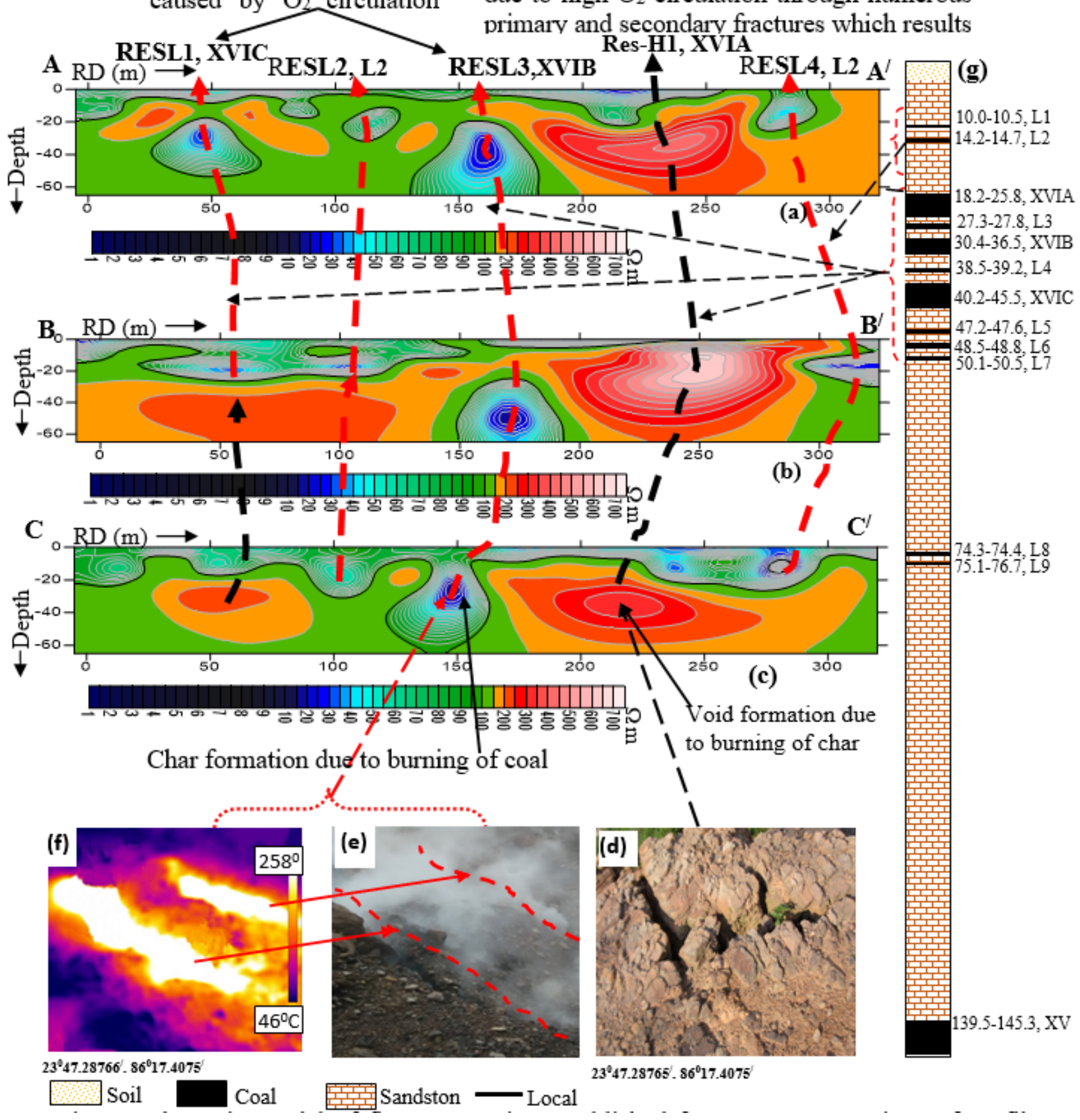

Figure 13

Model of fire propagation established from 2D ERT sections of profiles AA/ (a), BB/(b) and CC/ (c) using combined inversion of all arrays. Low resistivities indicate active coal fire. Field photograph showing numerous higher-order fractures/ cracks fissures, etc. ( $d$ \& e) and thermal image (f corresponds to e) over previous coal fire-affected areas. (g) Litholog of a nearby borehole (depth in meter). Low resistivity zones (Res-L1, Res-L3, Res-L2, Res-L4) indicate an active fire in coal seam XVIC, B and L1/ L2. Relatively high 
resistivity zone (Res-H1) represent cavities caused by the burning of char in high $\mathrm{O} 2$ environment through numerous primary and secondary fractures.

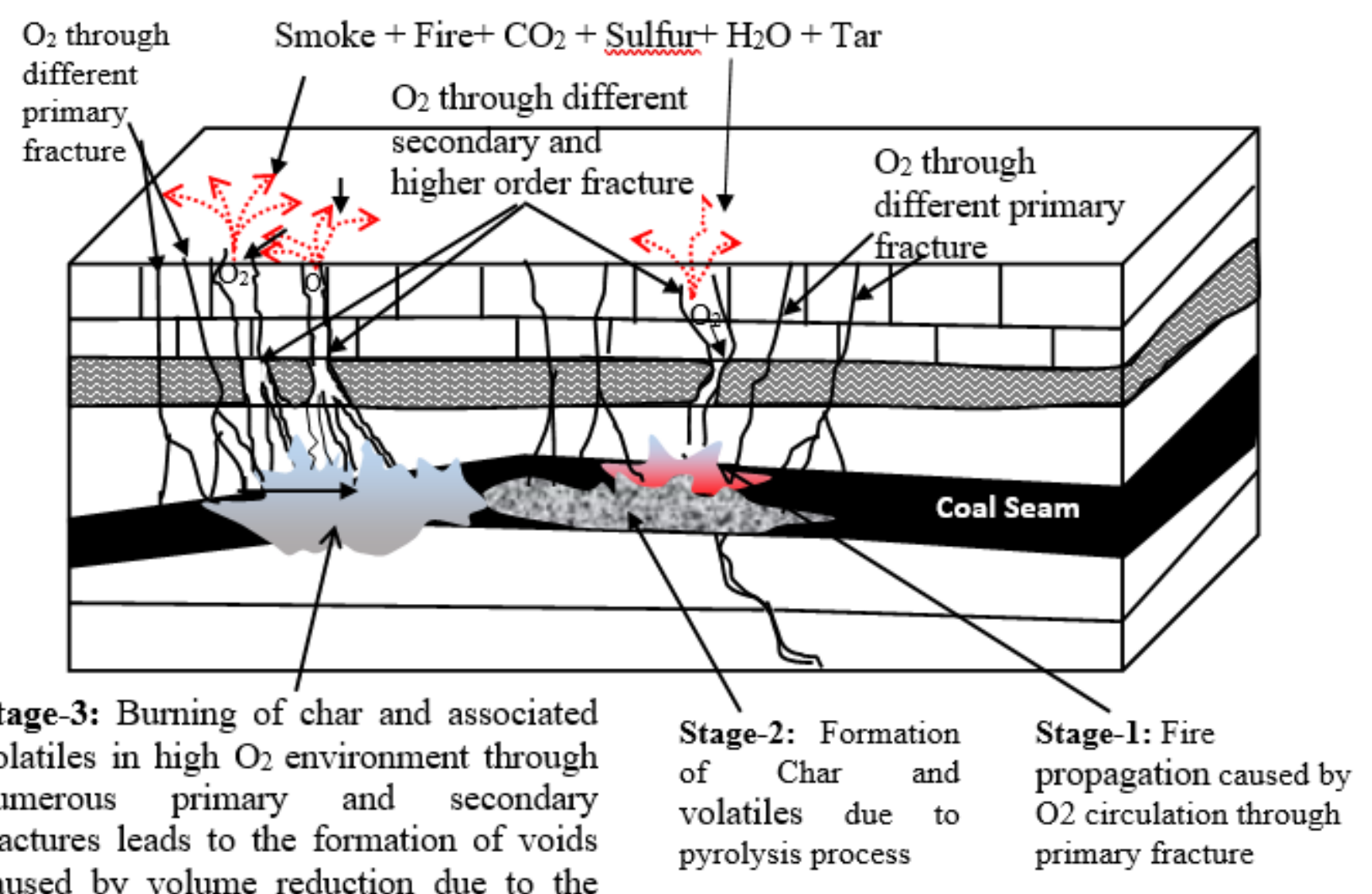
caused by volume reduction due to the transformation of coal to char and further to ashes mixed with rock debris

\section{Figure 14}

A conceptual model of coal combustion, char formation and void formation resulting from coal seam fire. 